\title{
New Nordic Peace
}

Nordic peace and conflict resolution efforts

Hagemann, Anine; Bramsen, Isabel

DOI:

10.6027/TN2019-524

Publication date:

2019

Citation for published version (APA):

Hagemann, A., \& Bramsen, I. (2019). New Nordic Peace: Nordic peace and conflict resolution efforts. Nordic Council of Ministers. TemaNord Vol. 2019 No. 524 https://doi.org/10.6027/TN2019-524 
(11) Nordic Council of Ministers

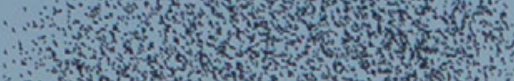

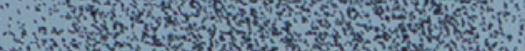

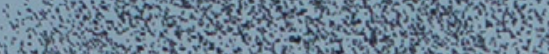

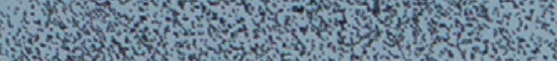

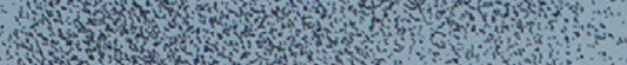
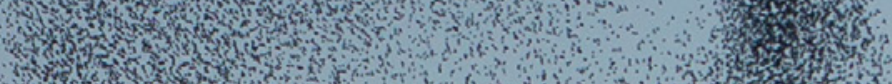

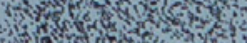

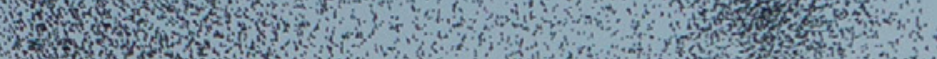

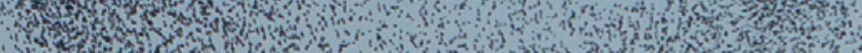

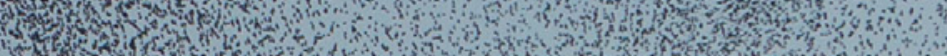
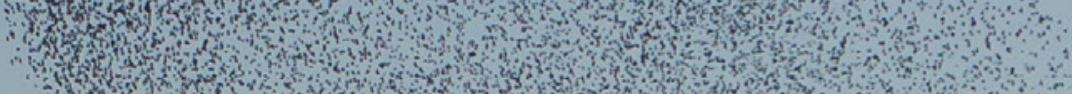

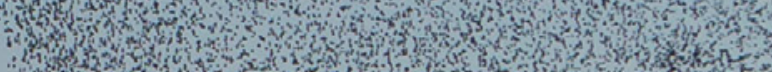

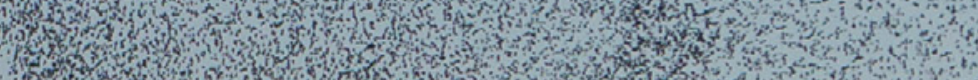

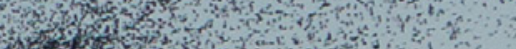

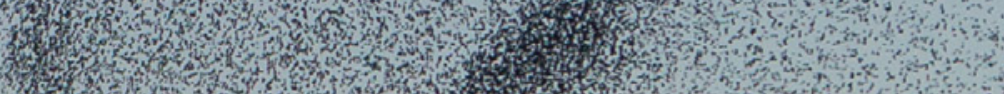

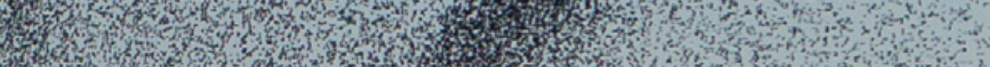

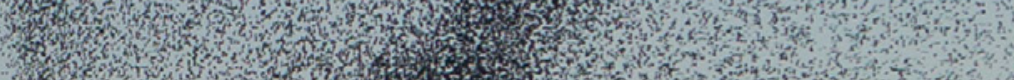

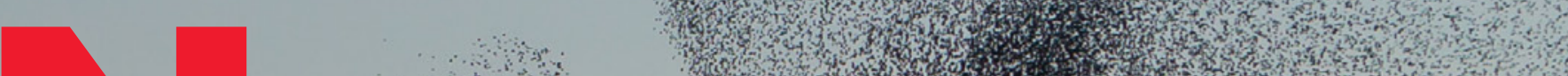

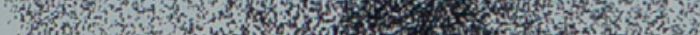

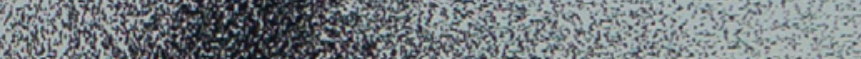

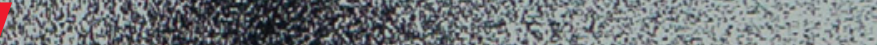

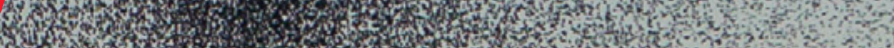

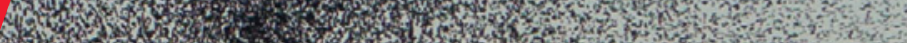

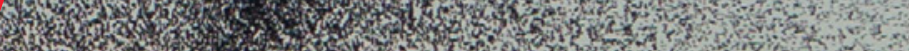

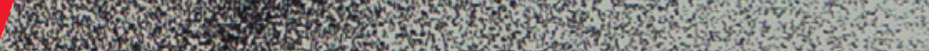

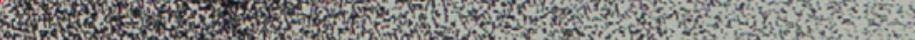

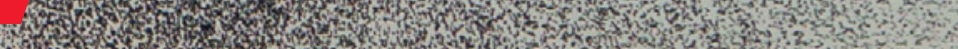
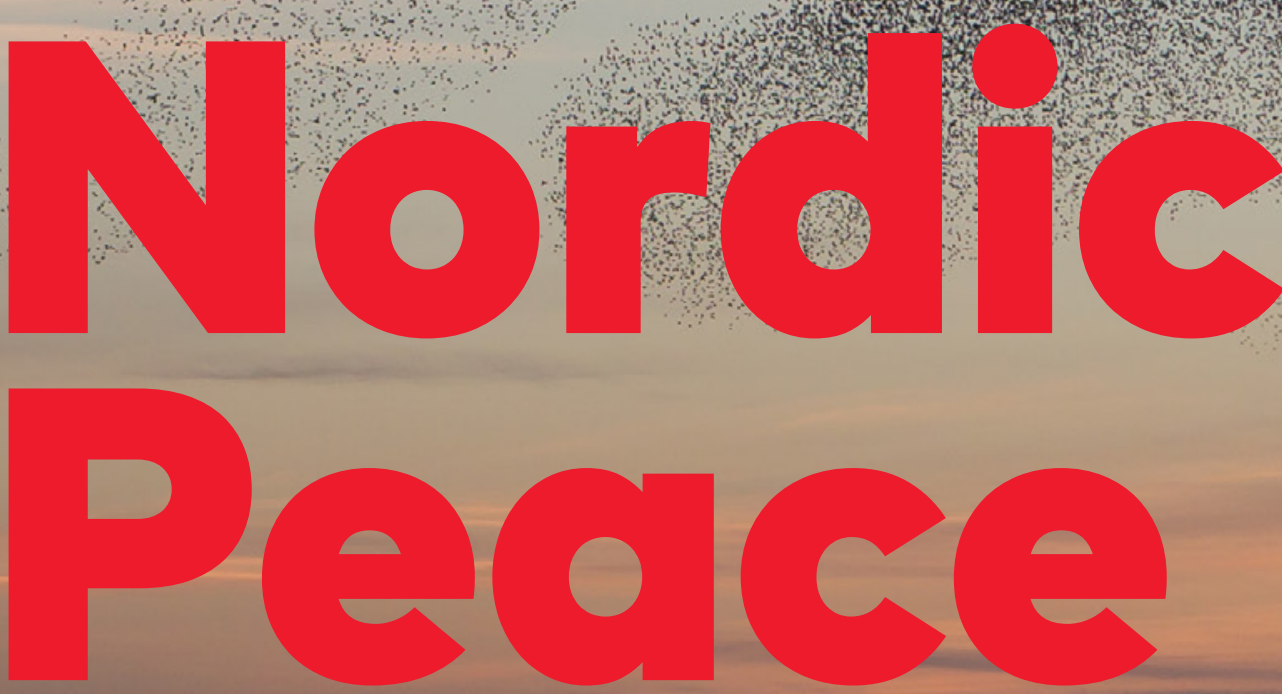


\section{New Nordic Peace}

Nordic Peace and Conflict Resolution Efforts

Anine Hagemann and Isabel Bramsen

TemaNord 2019:524 
Nordic Peace and Conflict Resolution Efforts

Anine Hagemann and Isabel Bramsen

ISBN 978-92-893-6142-2 (PRINT)

ISBN 978-92-893-6143-9 (PDF)

ISBN 978-92-893-6144-6 (EPUB)

http://dx.doi.org/10.6027/TN2019-524

TemaNord 2019:524

ISSN $0908-6692$

Standard: PDF/UA-1

ISO 14289-1

(c) Nordic Council of Ministers 2019

Cover photo: Lensmanzoo - stock.adobe.com. The cover photo shows starlings flying in murmuration formation at dusk. The phenomenon of murmuration can involve thousands of individual birds in flight forming a coherent three-dimensional cloud or shape. The concept of murmuration has been used in social science to capture networked ways of working together, something which this report explores the potential of for Nordic peace and conflict resolution efforts globally.

Print: Rosendahls

Printed in Denmark

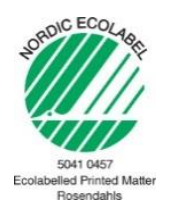

\section{Disclaimer}

This publication was funded by the Nordic Council of Ministers. However, the content does not necessarily reflect the Nordic Council of Ministers' views, opinions, attitudes or recommendations.

Rights and permissions

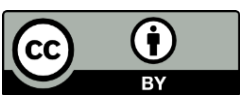

This work is made available under the Creative Commons Attribution 4.0 International license (CC BY 4.0) https://creativecommons.org/licenses/by/4.0

Translations: If you translate this work, please include the following disclaimer: This translation was not produced by the Nordic Council of Ministers and should not be construed as official. The Nordic Council of Ministers cannot be held responsible for the translation or any errors in it. 
Adaptations: If you adapt this work, please include the following disclaimer along with the attribution: This is an adaptation of an original work by the Nordic Council of Ministers. Responsibility for the views and opinions expressed in the adaptation rests solely with its author(s). The views and opinions in this adaptation have not been approved by the Nordic Council of Ministers.

Third-party content: The Nordic Council of Ministers does not necessarily own every single part of this work. The Nordic Council of Ministers cannot, therefore, guarantee that the reuse of third-party content does not infringe the copyright of the third party. If you wish to reuse any third-party content, you bear the risks associated with any such rights violations. You are responsible for determining whether there is a need to obtain permission for the use of third-party content, and if so, for obtaining the relevant permission from the copyright holder. Examples of third-party content may include, but are not limited to, tables, figures or images.

Photo rights (further permission required for reuse):

Any queries regarding rights and licences should be addressed to:

Nordic Council of Ministers/Publication Unit

Ved Stranden 18

DK-1061 Copenhagen $\mathrm{K}$

Denmark

Phone +4533960200

pub@norden.org

\section{Nordic co-operation}

Nordic co-operation is one of the world's most extensive forms of regional collaboration, involving Denmark, Finland, Iceland, Norway, Sweden, and the Faroe Islands, Greenland and Åland.

Nordic co-operation has firm traditions in politics, economics and culture and plays an important role in European and international forums. The Nordic community strives for a strong Nordic Region in a strong Europe.

Nordic co-operation promotes regional interests and values in a global world. The values shared by the Nordic countries help make the region one of the most innovative and competitive in the world.

The Nordic Council of Ministers

Nordens Hus

Ved Stranden 18

DK-1061 Copenhagen K, Denmark

Tel.: +4533960200

www.norden.org

Download Nordic publications at www.norden.org/nordpub 



\section{Contents}

Summary . .7

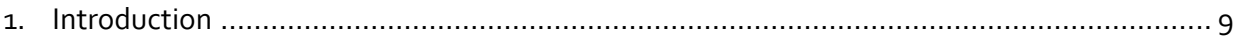

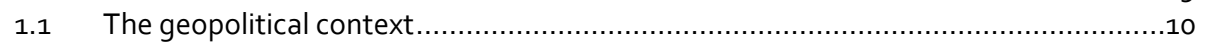

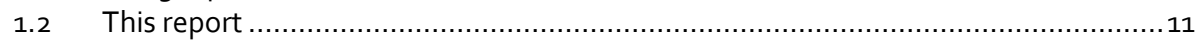

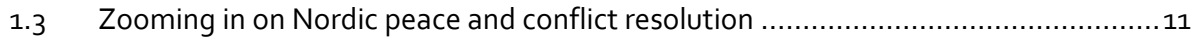

2. The Nordic Peace brand .................................................................................. 15

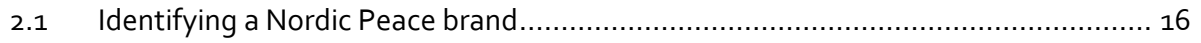

$2.2 \quad$ A Nordic umbrella of peace? .......................................................................

2.3 "Walking the talk": The Nordic way of leading by example ...................................18

2.4 Peaceful conflict resolution, mediation and dialogue .......................................... 19

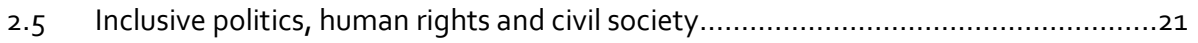

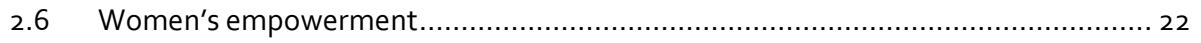

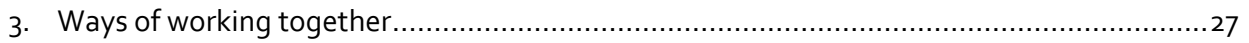

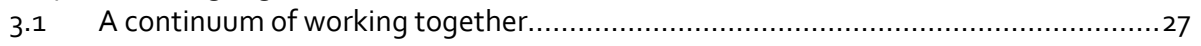

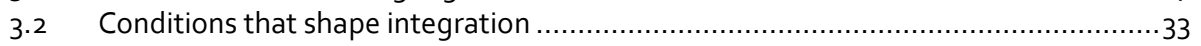

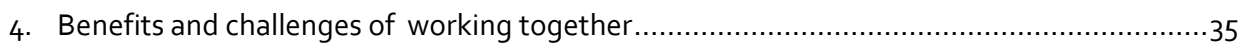

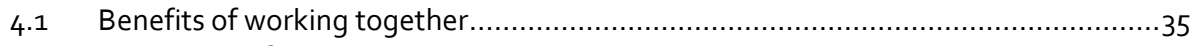

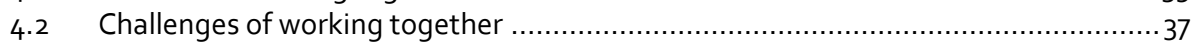

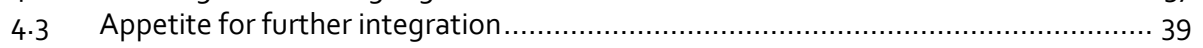

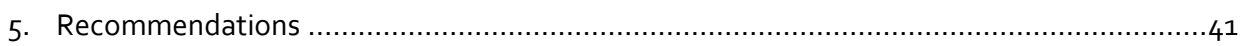

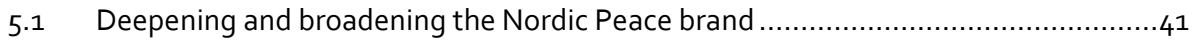

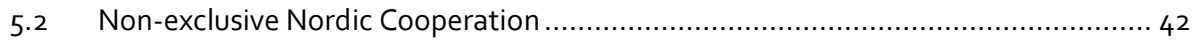

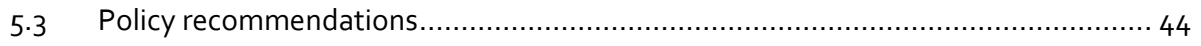

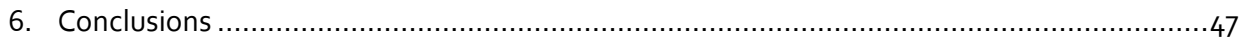

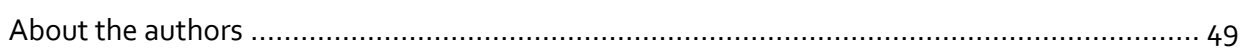

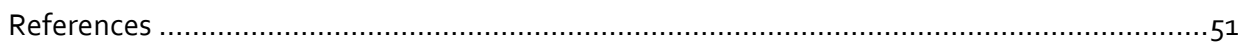

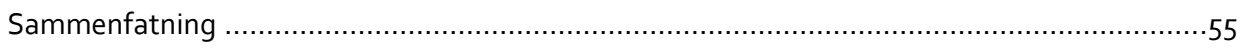




\section{Summary}

This report provides an overview of how Nordic countries currently work together on peace and conflict resolution. The report examines the Nordic tradition of supporting peace and conflict resolution efforts and whether an actual Nordic Peace brand exists. We find that a Nordic Peace brand, culture or tradition generally consists of two elements: core values and ways of working. As concerns core values, we investigate how and whether mediation, dialogue, human rights, civil society and women, peace and security, can be elements of a Nordic Peace brand. As regards the ways of working together, the report demonstrates how joint Nordic work on peace and conflict is generally driven by pragmatic like-mindedness and practical solutions. The report categorizes three different types and degrees of working together: coordination, as the least integrated approach, primarily involving information sharing and trust building; cooperation, as a more ritualized yet still politically non-committal form of working together; and collaboration, as a more regular, integrated and in some cases more binding approach, where joint analysis leads to joint solutions. We find that whereas there is often limited appetite for formalizing cooperation, there is a growing appetite among the Nordics to work together, both due to the practical benefits hereof but also due to geopolitical shifts in the Nordic neighbourhood, the increasing pushback against multilateralism and international norms globally. We also find that whereas certain policy areas may pose greater challenges for joint efforts, the benefits of working together count the potential to increase impact and gain information and that working together is made easier by shared working cultures, values and high levels of trust among the Nordics. Finally, we propose a set of recommendations regarding Nordic joint projects and potential mechanisms of working together. We suggest two areas that are particularly prone to increased collaboration: women, peace and security, on the one hand, and preventive diplomacy on the other. We further identify a new trend, "non-exclusive Nordic cooperation", where the Nordics work together along with regional and global actors, arguing that this serves as inspiration for future Nordic peace and conflict resolution efforts. 


\section{Introduction}

In recent years, the global geopolitical landscape has changed in ways that affect the immediate environment of the Nordic countries. In the current global world order, working together on peace and conflict resolution seems more important than ever. In 2009, the Stoltenberg Report revitalized the debate on joint Nordic foreign and security policy. Since then, a series of policy initiatives has demonstrated the growing political support for increased foreign, defence and security cooperation. Notably, further collaboration is the key message in the latest International Strategy for the Nordic Council for 2018-22. Parallel to this, the Nordics are working actively to promote a stronger brand for the region in a wide range of areas. These two processes were connected in 2017, when Nordic Council members launched the idea that "Peace should be made the trademark of the Nordics" and be prioritized as an important pillar of Nordic cooperation. This report is commissioned by the Nordic Council and financed by the Nordic Council of Ministers as part of a joint decision to map Nordic efforts globally to support peace and conflict resolution, including efforts to increase women's participation and influence.

The Nordic region, including Denmark, Finland, Iceland, Norway, Sweden, the Faroe Islands, Greenland, and the Åland Islands, is renowned for being a region of peace, where the resolution of internal conflicts by peaceful means has been its legacy for more than 200 years. But it is also known to be a region for peace in that the Nordics contribute to promoting peace and conflict resolution internationally. To support the deliberations in the Nordic Council of Ministers, the Nordic Council and the wider public in the Nordic countries, this report examines what working together on peace efforts actually entails at the working level, takes stock of the Nordic Peace brand and makes policy recommendations on widening and broadening Nordic cooperation on these matters.

In 2017, Anders Wivel, a professor of political science, wrote of how "anyone trying to identify a Nordic model for international peace and security today would be hard pressed." This report demonstrates that finding good examples of Nordics working together on peace and conflict resolution is not that hard after all. While the policies of Nordic countries differ significantly in some areas of peace and conflict resolution, the Nordics work together in many ways and on many levels. As one interviewee commented on dissimilar policies: "regardless of all this, there is always that 'constant' called Nordic cooperation." Especially at the country level, informal and formal structures facilitate collaboration, not least in conflict settings. Based on interviews with stakeholders from the respective Nordic ministries of foreign affairs, development agencies and their close implementing partners, we find that the Nordics often work together in a highly informal manner, partly due to the political structure of official Nordic cooperation, which does not include foreign and security policy. However, although often informal at the policy level, formalized practical structures can nonetheless lead to increased policy alignment. 


\subsection{The geopolitical context}

In recent years, the global geopolitical landscape has changed in ways affecting the immediate environment of the Nordic countries. Important fora for working together on foreign and security policy are under pressure and global security dynamics are shifting. These include US signals of increased hesitance in their support to the NATO alliance, Russian assertiveness in the European neighbourhood, and that the European Union is under increasing pressure as it struggles to find common solutions to the financial crisis, the migration crisis, and Brexit. Furthermore, the global pushback against a rule-based international order is putting new pressure on the UN and norms systems (e.g., human rights) of which the Nordics have always been strong advocates.

On the one hand, there are important differences among the Nordic countries and their interests in working together. While the Nordics form a geographic region and share strong cultural and linguistic bonds, they do not form a coherent strategic entity in terms of their foreign policies. Geographically, the qualities and interests of the Atlantic islands of Greenland, Iceland and the Faroe Islands, sometimes called "West Norden", are distinct from the countries on the European peninsula, as demonstrated most recently in questions regarding the Arctic. In terms of allies, Nordic strategies have also been divergent; Denmark and Norway are often portrayed as Atlanticists, whereas Finland, Sweden and Norway are the most sensitive towards Russian foreign policy. While Denmark, Iceland and Norway are NATO member states, Finland and Sweden have (formally) remained unaligned. Denmark, Finland and Sweden are EU members, while Iceland and Norway have opted to stay out of the Union (but are members of the European Economic Area). Yet Danish EU-scepticism and its resulting "opt-outs", including from European common security and defence policy - and opposite this, the recent Norwegian involvement in the new EU Common Defence Fund in the area of foreign and security policy - in some respects render Norway closer to the EU than Denmark.

At the same time, there is an increasing, common interest in Nordic cooperation on foreign and defence policy. Milestones include the Stoltenberg Report on Nordic Cooperation on Foreign and Security Policy in 2009, the establishment of a joint Nordic Defence Cooperation (NORDEFCO) in 2009 and subsequent initiatives, including a joint declaration of Nordic solidarity in 2011. Together, these developments demonstrate a new commitment to strengthened defence cooperation and to the projection of a more unified stance in the Baltic Sea region. The Nordics continue to work closely together where possible within the multilateral organizations. Interestingly, a recent example of this is the stated ambition of NORDEFCO to access funds from the new European Defence Fund, signaling ambitions both of deepening Nordic engagement on defence and an appetite for strengthening the Nordic approach to EU common defence. Moreover, there is a lengthy tradition in the region for actually working more closely together beneath the surface than above. Even under the much more constraining conditions of the Cold War, countries with different alignments did both collaborate actively and take each others' interests into account in unspoken ways; there is a lot to build on that makes formal structures less definitive than often assumed. 
Greenland, the Faroe Islands and Åland have status as autonomous regions within the Nordic countries. Research has shown that maintaining a constructive relationship to autonomous regions and the Nordic tradition of peaceful conflict resolution go hand in hand; especially strengthened by conflict prevention, trust-building and flexibility. The autonomous regions and Nordic perspectives on peace and conflict resolution in the Arctic are beyond the scope of this report, even though they clearly warrant further investigation. This report focuses on the five Nordic states and efforts within their foreign policies, broadly understood, to promote peace and conflict resolution.

\subsection{This report}

Against the backdrop of geopolitical and policy developments, this report begins with the people working with Nordic cooperation or peace and conflict resolution as part of the foreign policies of the Nordic countries. The study was commissioned by the Nordic Council and financed by the Nordic Council of Ministers and builds on thorough analysis of existing policy documents from the Nordic Council and the respective Nordic governments together with a wide array of publicly available written material about the activities of the Nordic countries at home and abroad. The bulk of the analysis is based on 32 semi-structured interviews with 49 individuals carried out in January, February and March 2019. We have sought to ensure broad representation among the Nordic countries and we have spoken to a sample spanning the most senior level (minister level) to junior officers. We have spoken to representatives from various organizations, including bureaucrats from the respective foreign ministries working on Nordic cooperation and conflict resolution, respectively; ambassadors; government development agencies; key implementing agencies of Nordic peace and reconciliation efforts, as well as a few academics, politicians and advisors working in the context of the Nordic Council and the Nordic Council of Ministers. Interviews were conducted in the capitals of Denmark, Sweden, Norway and Finland and via telephone. In the interviews, we asked about the general efforts in peace and conflict resolution, whether the Nordic Peace brand resonated in their work, how practitioners work together with the other Nordics, and discussed potentials as well as limitations on working closer together.

\subsection{Zooming in on Nordic peace and conflict resolution}

The Nordic efforts to promote peace and conflict resolution are part of the countries' foreign, security and development policies. "Peace and conflict resolution" is used as a broad term in this report, which covers peacebuilding, conflict prevention, mediation and reconciliation. It includes both direct efforts to make peace and more structural efforts to support and build resilience, human rights, rule of law and support longer-term sustainable development. This section outlines the priority and substance given to the Nordic and to peace and conflict resolution in the policies of the Nordic countries. 


\subsubsection{Locating the Nordic within foreign policy}

All of the Nordic countries mention the Nordic in their foreign- and development policies, but with varying emphasis. The Swedish, Danish and Icelandic interviewees mentioned the EU as their primary arena for coordinating foreign policy, including peacebuilding efforts. Finnish documents and interviewees also emphasized the importance of the EU, but the bilateral relationship to Sweden was of equal importance. The Finnish foreign policy underlines the importance and centrality of continued Nordic foreign and security cooperation, both as a means to ensure Finnish interests and security as well as to increase influence globally. Finnish foreign and defence policy is very oriented towards Sweden, and the Nordic community is the next immediate sphere of importance. While Nordic cooperation is one of the cornerstones of the foreign policy of Iceland, Iceland does not elaborate further on what this entails. In the platform for the Icelandic presidency of the Nordic Council of Ministers for 2019, Iceland pushes for a joint Nordic focus on peace and disarmament, underscoring the existence of a Nordic Peace brand. Like Iceland, Nordic cooperation is a cornerstone in Norwegian foreign policy, linking a strong Nordic voice to issues relating to the UN and climate change. Sweden highlights Nordic cooperation in connection with specific foreign policy issues, such as mediation, the women, peace and security agenda, and disarmament. Denmark introduces its foreign and security policy with a reference to the Nordics as Denmark's closest "value community" but does not mention Nordic cooperation anywhere else. That the government documents of several countries reference "the Nordic" without elaborating on what these values are or how they translate into policy signals a political hesitance to operationalize Nordic common foreign policy values and priorities in practice, reflecting the informal status of Nordic cooperation on foreign and security policy. It also indicates that understandings of and references to the Nordic community are often implicitly assumed and taken for granted. These dynamics are further discussed below.

\subsubsection{Locating peace and reconciliation within foreign policy}

All five Nordic countries place emphasis on conflict-affected, fragile states. All of the Nordics are top performers when it comes to per capita contributions to fragile states despite the cuts to foreign policy and development funding in several countries. Counted together, the collective Nordic contribution is a little over $8 \%$ of the total amount of funds from all DAC donors to fragile states, making them the fifth largest bilateral donor. Looking at the priority countries for each of the Nordic countries, the focus on fragility and conflict is also clear.

Although the five Nordic countries all place strong emphasis on peace and conflict resolution in their foreign policies, they have different entry points and terminologies. Finnish policies outline mediation as a key peacebuilding tool, an agenda they seek to further with the other Nordic countries. Sweden too emphasizes peacebuilding, closely in line with the priority given to the women, peace and security agenda in light of the Swedish Feminist Foreign Policy, which strives to strengthen the rights, representation and resources of women and girls globally. Iceland highlights the peaceful resolution of 
disputes as an important principle in their foreign policy. An Icelandic Ministry of Foreign Affairs (MFA) representative stressed that the goal of their foreign policy as being "peaceful conflict resolution, that is; prevention, diplomacy, dialogue instead of having have to go through conflict and stop them afterwards." Norway promotes an agenda of peace and reconciliation, which is highlighted as an important part of their foreign policy. The Norwegian government connects this agenda to Norway's role in international politics as an impartial facilitator of dialogue. Danish peace efforts are closely linked to stabilization efforts and "whole-of-government approaches", leaning more toward British and American policy language. The Nordics have a strong tradition of support to multilateral peacekeeping; an important area within peace and conflict resolution, which was not part of the commission for this report, but which warrants further attention and could be linked to a Nordic Peace brand, as suggested in the final recommendations. The figure below summarizes the respective Nordic policies on peace and conflict resolution.

Table 1: Differing Nordic priorities within peace and conflict resolution

\begin{tabular}{|c|c|c|c|}
\hline & Key word & Peace efforts & Nordic cooperation \\
\hline Denmark & Stability & $\begin{array}{l}\text { "Peace, stability, protection" } \\
\text { (DK strategy on dev. policy } 2017,5 \text { ) }\end{array}$ & $\begin{array}{l}\text { The Nordics = Denmark's closest "value } \\
\text { community" } \\
\text { (DK FP strategy } 2018,15 \text { ) }\end{array}$ \\
\hline Sweden & Peacebuilding & $\begin{array}{l}\text { Swedish peace efforts are coupled } \\
\text { closely to the "women, peace and secu- } \\
\text { rity"-agenda } \\
\text { (Handbook: Sweden's feminist FP, 2018; } \\
\text { Policy for global dev. in the implementa- } \\
\text { tion of the } 2030 \text { agenda) }\end{array}$ & $\begin{array}{l}\text { Nordic cooperation on FP is highlighted } \\
\text { with regards to issues such as medita- } \\
\text { tion, the "women, peace and security"- } \\
\text { agenda, and disarmament } \\
\text { (Handbook: Sweden's feminist FP, 2018) }\end{array}$ \\
\hline Norway & Reconciliation & $\begin{array}{l}\text { Peace and reconciliation = central to } \\
\text { Norway's FP. Norway as impartial } \\
\text { facilitator } \\
\text { (FP address to Storting 2018) }\end{array}$ & $\begin{array}{l}\text { Nordic cooperation = cornerstone in Nor- } \\
\text { way's FP } \\
\text { (FP address to the Storting 2018) }\end{array}$ \\
\hline Iceland & Resolution & $\begin{array}{l}\text { Peaceful resolution of disputes = impor- } \\
\text { tant principle in Icelandic FP } \\
\text { (Icelandic government } 2017,36 \text { ) }\end{array}$ & $\begin{array}{l}\text { Nordic cooperation = cornerstone of Ice- } \\
\text { land's FP } \\
\text { (Icelandic government 2017, 35) }\end{array}$ \\
\hline Finland & Mediation & $\begin{array}{l}\text { Mediation = key tool in peacebuilding } \\
\text { (Finland Action Plan for Mediation 2011, } \\
\text { 9, 23; Findland Gov Report on FP 2016, 28) }\end{array}$ & $\begin{array}{l}\text { Continued stress on the importance of } \\
\text { continued Nordic foreign and security } \\
\text { cooperation. Finland relates the Nordic } \\
\text { cooperation first to Sweden and sec- } \\
\text { ondly to the wider Nordic community } \\
\text { (Fin rep on FP, 2016, 12-13,21-22) }\end{array}$ \\
\hline
\end{tabular}

Further, the meanings attributed to "peace", "reconciliation", "security" and "mediation" differ considerably in the different Nordic countries, rooted both in linguistic and cultural differences. The Finnish word for mediation, Rauhanvälitys, has a very broad meaning, alluding to development, coexistence and inclusion, and is therefore a good overarching word to describe dialogue and peacebuilding activities. This runs counter to the Norwegian, Swedish and Danish use of megling/mäkling/mægling, respectively, referring to a specific activity related to third-party support to the dialogue of conflicting parties. Norwegian policy documents and interviewees use the title "peace and reconciliation" to refer relatively narrowly to track one and two - mediation and mediation support - which are central elements in their foreign policy. 
Swedish policy documents and interviewees spoke in broader terms of peace and security, human security and peacebuilding. Iceland uses "peace and disarmament" and "peaceful conflict resolution" as overall categories describing their efforts. Finally, Danish policies and interviewees placed greater emphasis on whole-of-government approaches including civilian-military coordination and stabilization, whereas peace and conflict prevention had a clearer emphasis in the context of multilateral cooperation. 


\section{The Nordic Peace brand}

The Nordic Council recently made the statement, "Låt fred bli Nordens varumärke" ("Let peace be the trademark of the Nordic region"), arguing that the Nordic Peace brand holds substantial potential. This was substantiated with reference to the long Nordic history of peace being a decisive factor enabling Nordic cooperation and welfare and because the Nordic countries have a track record of engaging in promoting peace and resolving conflicts globally. Regarding the first dimension, the internal peace within the North relates both to the peaceful relationship between the Nordics, running back at least to 1905 with the non-war between Norway and Sweden as well as the peaceful living conditions within the Nordic countries, with welfare states, equality and democracy securing low levels of structural violence. Regarding the second: for most of the twentieth century and the twenty-first century thus far, the involvement of the Nordic countries abroad in foreign, development and humanitarian policy has generally placed emphasis on building inclusive societies and resolving political conflict in peaceful ways. The following section explores whether the Nordic Peace brand is something that resonates in 2019 with practitioners and what they associated with a Nordic Peace brand.

The roots of the Nordic Peace brand abroad: The tradition for peaceful yet political engagement is born

The Nordic Peace brand abroad grew strong during the Cold War, when the Nordic region managed to remain disengaged from high-tension activities and did not support deployments of foreign troops and nuclear weapons despite their strategic alignments and the nearby military presence of both Soviet and American superpowers. Simultaneously, the Nordics were involved in a number of liberation struggles during the Cold War. One historical account of this period highlights how, during the Cold War, "the Nordic countries were unique in the Western world in their support to individuals, organisations and refugees, struggling to end institutionalised colonialism and racism and alleviate their humanitarian consequences." Another writes of how, in contrast to the Western resistance to "Soviet-backed" nationalist movements, the "label of Nordic-backed" movements was "a less dramatic label", and that these were generally mainly concerned with "the non-military aspects of the struggles".

One example mentioned by interviewees from several Nordic countries is the engagement in South Africa. Norway, Sweden, Finland and Denmark were all engaged in the anti-apartheid struggle, primarily through civilian and humanitarian support. Interviewees mentioned their respective countries' involvement in South Africa as an engagement which played an important role in shaping the "peacebuilding" element in their foreign and development policies. In addition to the support to liberal, democratic values, this engagement was very much foundational in terms of how it was structured, including strong support to civil society and humanitarian programs in South Africa. At the same time, it was further motivated by a growing indignation and involvement by the citizens and the public in the Nordic countries. Interviewees mentioned a very strong common-Nordic platform for coordination in the country, especially in the last decades of the struggle in the 1980 and gos. This had come to represent, institutionally, an example of a common-Nordic success as well as 
a model for working together, which had the strong Nordic characteristic of deeply invested civilsociety engagement encompassing a model for comprehensive support to a political struggle for rights and democracy.

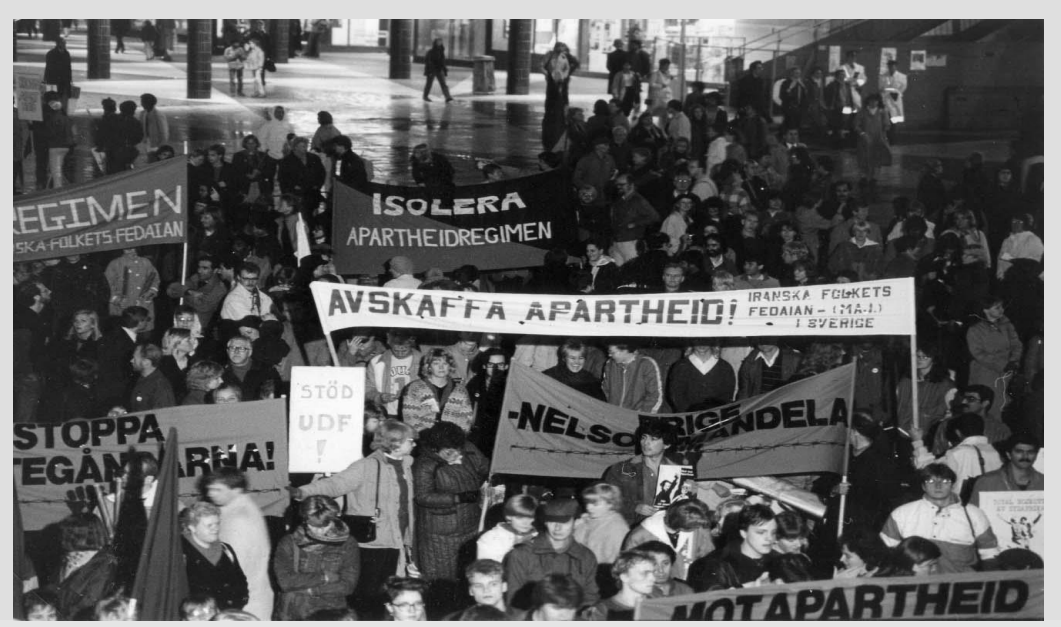

Note: The Nordic countries' engagement in the anti-apartheid struggles in South Africa were tied to strong civil society movements at home. Here, Swedish demonstrators protest against apartheid at Sergelstorg, Stockholm, Sweden in the 1980s.

Source: The Nordic Africa Institute.

\subsection{Identifying a Nordic Peace brand}

The interviews took stock of whether practitioners identified with a Nordic Peace brand and saw the potential in it. We found varying degrees of adherence to such a brand per se; some interviewee definitely identified a distinct Nordic brand of peace whereas others did not. When speaking more broadly about the tradition or culture of working towards peace among the Nordics abroad, however, this resonated with the practitioners working both on Nordic issues and those working within peace and conflict resolution. Most people recognized the Nordic brand or "tradition", as some called it; fewer had a conception of a Nordic Peace brand as such. For example, one interviewee questioned; "are we somehow the voice for peace internationally? I'm not sure to be honest - I'm not sure we are seen as such by others." Another interviewee described a sort of revival of the Nordic peace brand: "A few years ago there was a lot of discussion that the Nordic brand was dead. But it is still there at every level, at the informal and formal level: On every level you have Nordic cooperation and on every level it gives us influence." In figure 1, we have collated a bucket list of the words that people associated with the Nordic brand and the Nordic Peace brand. We found that their formulations of Nordic Peace concentrated around two types of characteristics: substantive values and ways of working or approaches. 


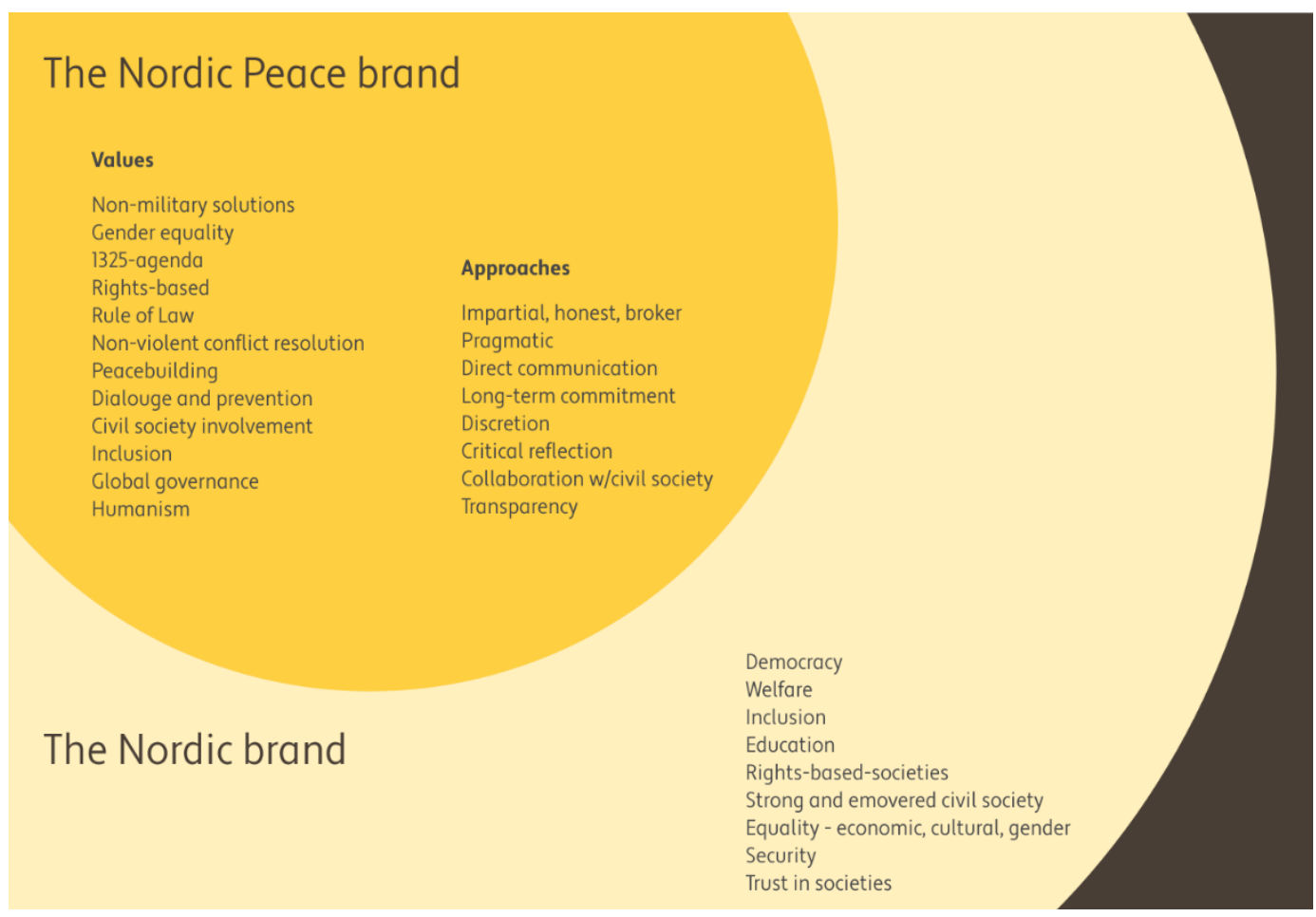

Figure 1 shows how, in terms of values, classic Nordic values such as democracy, equality and inclusion were a central theme. Adding to this, the similarity among the Nordics in their approaches and ways of working, both in terms of organization and working culture, was emphasized in practically all of the interviews in different ways. If we condense the responses, we find that a Nordic Peace brand can be narrowed down to the following:

Figure 2: The Nordic Peace brand, condensed

1. Approach: Impartiality and long-term commitment

2. Values: Democracy, human rights, equality

3. Peace and Conflict approach: Prevention, dialogue, inclusion 


\subsection{A Nordic umbrella of peace?}

In some instances, interviewees would revert to their own national brand of peace when asked about the Nordic. The representatives from countries with a more outspoken national brand of peace clearly saw less of a need for a Nordic Peace brand, whereas others were more open to common Nordic branding around peace, and others yet found very useful and necessary. This made it clear that if more efforts were to go into thinking about an active branding strategy around peace, the brand should not narrowly concentrate on what individual countries already have or wish to have a strong profile on; rather, it should be broad enough in order to encompass the Nordics and leave space for individual room for maneuvering within a "Nordic umbrella of peace". The benefits to working together, which is devoted a section below, further goes to the advantages of joint Nordic efforts.

The analysis of the general global push-back against the liberal international order, democracy and the rule of law was mentioned in most of the interviews, and this tendency was clearly perceived as a threat to the common Nordic values. Most of the interviewees agreed that this was a negative tendency and that it necessitated a stronger Nordic response. Specifically, in this environment of increased hostility towards liberal values and multilateral cooperation in general, many interviewees told stories of how, the Nordics previously pushed for increasingly progressive agendas, whereas the current challenge was simply to defend agreed upon language, for example in the multilateral arena. Somehow partly because of this, however, values associated with the Nordic brand were also gaining traction and rallying supporters. As one interviewee explained: "In a sense our brand is under attack, but then this also has the effect that our brand is getting stronger and gaining support." This tendency is described further in the examples of cooperation in the multilateral arena. In the following, we examine both the ways of working together among the Nordics, and provide examples of substantive areas where the Nordic values overlap.

\section{3 "Walking the talk": The Nordic way of leading by example}

One key argument for the particular strength and legitimacy of the Nordic brand was the coherence between the internal dynamics in the region and the foreign policies. Many interviewees emphasized how the internal peace within the Nordic countries was a factor that had been mobilized to inspire other regions. The Balkans and Africa were mentioned as areas where the Nordics worked together to brand peaceful relations by demonstrating their ability to collaborate across embassies and policy areas, thereby leading by example. The peaceful resolution of conflicts within the North is also emphasized in relation to the Åland Islands, where the Åland Islands Peace Institute, the Åland government and the Finnish government actively promote the Åland example in international contexts as a model to learn from.

While the legacy of peaceful relations, democracy and welfare speak their own language, the importance of "walking the talk" in all policy areas and constantly reevaluating 
oneself was mentioned in many interviews. This includes showcasing own examples and challenges as well as making efforts concrete and relatable. Strong emphasis on the Nordic brand risked backfiring or alienating interlocutors when the Nordics landed in a category of self-perceived "moral superiority". The Nordic strategy within peace and conflict resolution had therefore been twofold. First, to build broader coalitions across continents, which is described below in the section on non-exclusive Nordic cooperation. Secondly, to "walk the talk" and increasingly reorient itself to do what it promoted (e.g., taking women's empowerment seriously) meant not only highlighting what had been accomplished in the Nordic countries but also being open and concrete about what was being done actively to deal with the many challenges still prevalent in the Nordic countries. This is also evident in the new generation of National Action Plans for Women, Peace and Security; the importance of leading by example was the new Nordic way. This is described in greater detail in the section on women, peace and security below. The Nordic tradition of linking being a region of peace internally to being a region for peace externally has its roots in Nordic history, and the following sections demonstrate how a new Nordic Peace brand entails different efforts to rethink and revitalize these connections.

\subsection{Peaceful conflict resolution, mediation and dialogue}

Dialogue and mediation are at the heart of peace and conflict resolution for several of the Nordic countries, and formed a cornerstone in the Nordic Council's suggestion of having peace as part of the Nordic brand. We will therefore present the different dialogue efforts here and discuss whether and how this is (or could be) part of a joint Nordic Peace brand.

Norway was the first country to invest in and prioritize work in the facilitation of peace talks. With the Oslo Accords (a set of agreements between the Government of Israel and the Palestine Liberation Organization (PLO) in the early 1990 s and the attention that came with them, Norway began to specialize in the facilitation of peace negotiations. Norway has since facilitated several such processes, both publicly and behind the scenes, both as a country as well as providing experts to processes under other auspices (e.g., in the UN). These include Bosnia, Sri Lanka, Sudan, The Philippines, Colombia and Afghanistan. The Norwegian work on facilitating peace processes is conducted by a special section on peace and reconciliation within the MFA (established in 2003) with support from Norwegian Centre for Conflict Resolution, NOREF. The section for peace and reconciliation count 14 people and has a budget of EUR 4.47 million. A representative from the section on peace and reconciliation in the Norwegian MFA summed up the overall aim of their work as follows: "To contribute to bringing parties to the table - and once they are at the table, contribute to them finding a peace agreement, and then of course also accompanying them in the implementation phase."

Finland has specialized less in formal peace talks and engaged more in mediation support, informal dialogue and grassroots engagements. Whereas Finland has been engaged in mediation for a long time, most notably former President Ahtisaari, the official policy emphasis on mediation is a more recent development. In 2010, Finland's former Minister for Foreign Affairs stated that Finland aimed to become a great power in mediation, 
which was followed by a Finnish National Action Plan for Mediation in 2011. Finland has a section within its MFA specifically focused on mediation, similar to Norway, but with fewer personnel. However, most of Finland's mediation work goes through Finnish NGOs and private organizations, such as the Crisis Management Institute (CMI). Research on Finish mediation efforts from 2018 shows how the Finnish mediation is rooted in a "Nordic model" with a strong link and high trust between civil society and the official sectors in mediation. This was also emphasized by interviewees. Finland's overall mediation efforts, broadly defined, have a budget of around EUR 13 million, whereas the mediation team consisting of five people is allocated EUR 500,000 annually.

In 2016, Sweden refocused its attention and resources on official mediation and actively reasserted itself as a peace actor. The rationale behind this prioritization was that Sweden already invested heavily in the development cooperation with conflict-affected countries and that Sweden could contribute further by also using the diplomatic tool box in a more pro-active and systematic manner. As one interviewee commented, "There was this discussion on trying to re-assert Sweden once again as a peace actor in the international field. The sense was that yes we have a peace tradition (...) and can we do more, in complementarity and coordination with the activities of the UN, the EU? Can we explore an increased agency for Sweden to contribute even more to peace?" Sweden has recently been engaged in the peace talks between North and South Korea as well as the talks regarding Yemen. There is a special section working on dialogue and peace processes in the Swedish MFA with three people. The decentralized Swedish organization means that geographical departments in Swedish Embassies play an important role. Several Swedish interviews emphasized a Swedish "bottom-up approach" with links to civil society and a lengthy history of engagement in conflict-ridden contexts that could support work on formal peace talks. Sweden also works to promote a more inclusive approach in relevant formal peace processes by making better use of the experiences and expertise available at the local level and within civil society.

While mediation - understood narrowly as peace talks between warring parties - is not a priority for Denmark, through its development assistance and civil society partnerships, the Danish government supports religious, humanitarian and preventive dialogue efforts in the Sahel region, the Middle East, Asia and the Horn of Africa. Danish efforts on dialogue and conflict resolution are mainly funded at the local and national levels due to Danish development aid being decentralized, meaning that decisions regarding development aid are taken at the embassy level, which enables high local-level flexibility and ownership. Moreover, the Danish MFA and the development agency, DANIDA, are integrated, meaning that policy integration across foreign, development and humanitarian areas is high. Like Denmark, Iceland does not prioritize the facilitation of formal peace talks, but peaceful conflict resolution is central to the Icelandic foreign policy strategy, which they support and engage in through their Crisis Support Unit.

While peace mediation is certainly a strong element in the national brand of several of the Nordic countries and could therefore be promoted as part of a Nordic brand, it is important to keep in mind that it is not a priority for all of the Nordic countries; at least not in a narrow sense. One solution is therefore to reorient the focus on peace mediation to include dialogue initiatives and de-escalation efforts more broadly, both during 
several stages of conflicts (from prevention to post conflict) as well as at different layers and groups of society, including civil society. The Nordic Women Mediators initiative, which has a separate section in this report, offers a good example of how Denmark, Norway, Sweden, Finland and Iceland have come together under the umbrella of mediation - but understood broadly as including peacebuilding and dialogue initiatives.

As we will return to in the section on the benefits and challenges of working together, it is also complicated to cooperate on the facilitation of peace talks due to the necessity of confidentiality in mediation processes as well as the difficulty of sharing the political goodwill that comes with having assisted parties in reaching a peace agreement. A broader conception of mediation and dialogue also enables further cooperation with division of labour, which again is central if there is political will to promote peace mediation or conflict resolution as a Nordic trademark.

\subsection{Inclusive politics, human rights and civil society}

Support to civil society is a legacy of the international development engagements of the Nordics and provides a good example of both dimensions of the Nordic Peace brand; the values involved as well as the ways of working within politics and society. Many interviewees highlighted the connection between the Nordic culture of transparency and open government and the active involvement in political processes of civil society at home, on the one hand, with the emphasis on the need to strengthen civil society abroad as a measure for democratic development and the non-violent resolution of conflicts on the other. Many interviewees also mentioned the comparative advantage of their national approach as well as the Nordic approach having to do with particular qualities around a deep political, long-term and context-sensitive engagement. There is a Nordic commonality in the traditions of investing in human resources, bottom-up engagement of civil society and long term engagement, especially in development assistance. Supporting a strong, vibrant civil society is a condition for enabling horizontal and vertical inclusion as well as a key check and balance to those in power. Nordic civil society engagements have especially emphasized the reduction of inequalities as well as working with state authorities to strengthen their ability to interact productively with groups outside government, for instance in the area of human rights. In the interviews, longterm presence and strategic patience in terms of support were highlighted as keys to enable the support of civil society and mechanisms of dialogues across sectors. Giving core funding to organizations as opposed to project support was another way of supporting the survival and growth of a sector.

According to the interviewees, the deep engagement and long-term investments in civil society promote at least three outcomes in relation to peace and conflict resolution. First, the Nordics enjoy high legitimacy trust due to their long-term engagements being closely connected to not promoting a certain agenda. Second, the Nordics gained knowledge of the societies in which they operate, not least a contextual understanding of the national and regional political dynamics which could feed into conflict analysis. This capacity was related to the ability to foresee, prevent and resolve conflict. Not that 
the Nordics were always able to act, but the deep political engagement and understanding was mentioned as a necessary condition for being able to do so. Third, due to the previous two outcomes, these types of engagements meant that Nordic countries had found themselves well placed in several cases to get involved in conflict resolution. Examples from Africa, South America and Asia were mentioned, where deep, longterm engagement in civil society was a fruitful platform from which to support or directly facilitate mediation processes.

\subsection{Women's empowerment}

The promotion of the women, peace and security agenda remains a cornerstone in the foreign policy of all of the Nordic countries. There are various formal structures for coordinating women, peace and security efforts, including the Nordic Forum, the NordicBaltic Forum as well as the Nordic Women Mediators. The latter is discussed below.

The area of women's empowerment and the agenda on women, peace and security (particularly in a peace and conflict context) are areas in which the Nordics share a very strong value alignment and where each of them have managed to establish a distinct profile. Denmark was the first country to draft a National Action Plan (NAP) for the implementation of UN Security Council Resolution 1325 on Women, Peace and Security in 2005. Since then, all of the Nordic countries have made several NAPs for women, peace and security. The main objectives of UNSC Resolution 1325 are to: 1) support the participation of women, 2) protect women and girls in armed conflicts and 3) mainstream gender perspectives in peace processes. A report from 2014 on the Nordic implementation of UNSCR 1325 evaluates the different NAPs and finds that "The objectives as such set in the Nordic NAPs often remain on a rather abstract level." As pointed out in several interviews, however, there is a process to ensure more concrete and measurable action plans on women, peace and security. For example, the recent Norwegian NAP launched in January 2019 has included a results framework, with specific results and indicators of these results listed. The newest Icelandic NAP has focused on narrowing its scope in order to set obtainable goals. This is done by first making sure that gender equality education and awareness is substantial at all levels in Icelandic society. One interviewee mentioned that if people do not fundamentally understand and support why women's empowerment is important for everyone, they cannot possibly be expected to explain it to anyone else or to work to improve it. Across the board, the tendency in the latest "generations" of NAPs in the Nordic countries is to be slightly more inward-looking and focused on living up to the standards that are advocated, in terms of demonstrating that the Nordic countries are indeed "walking the talk", in this area and spearheading innovative ways to include gender equality in their own systems, policies and societies. This is also the case with a number of other initiatives that interviewees highlighted.

By virtue of its recently adopted feminist foreign policy, Sweden has been particularly vocal on the promotion of gender equality in foreign policy. Sweden's ambition during their tenure as a UN Security Council member, for example, was to include references to women, peace and security in all resolutions, which was unprecedented. 
"This Government is pursuing a feminist foreign policy that aims to strengthen women's rights, representation and resources."

- Margot Wallström, Minister for Foreign Affairs

\#FemForeignPolicy

Government Offices of Sweden Ministry for Foreign Affairs

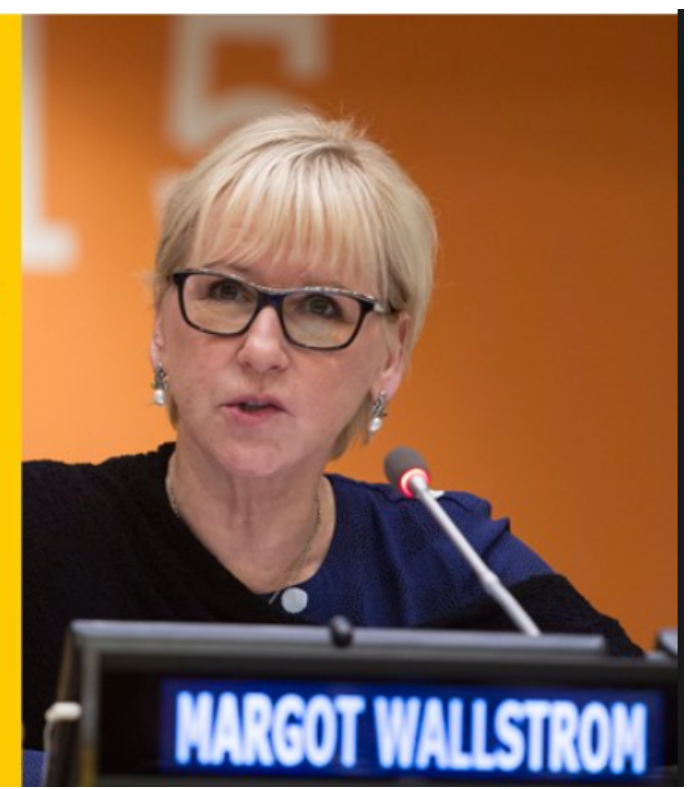

Note: The Swedish feminist foreign policy has made its mark in demonstrating what a foreign policy with women's inclusion at its forefront can look like, with a focus on "three R's": Women's rights, representation and resources.

Source: Government of Sweden.

Another example of a Nordic country's distinct profile in the area of women's empowerment and the importance of gender equality for peaceful societies is the Icelandic "Barbershop Initiative", which organized sessions with men to raise awareness about why gender equality is important to men as well as women and why and how men can engage in supporting the gender equality movement. It is also an excellent example of a well-orchestrated branding strategy and something, that was mentioned in several interviews with other Nordics than Iceland: how a very concrete and simple initiative with limited resources hit the bulls-eye in terms of putting the gender equality discussion at the forefront while also branding Iceland very effectively as a country with a clear profile on women's empowerment. 


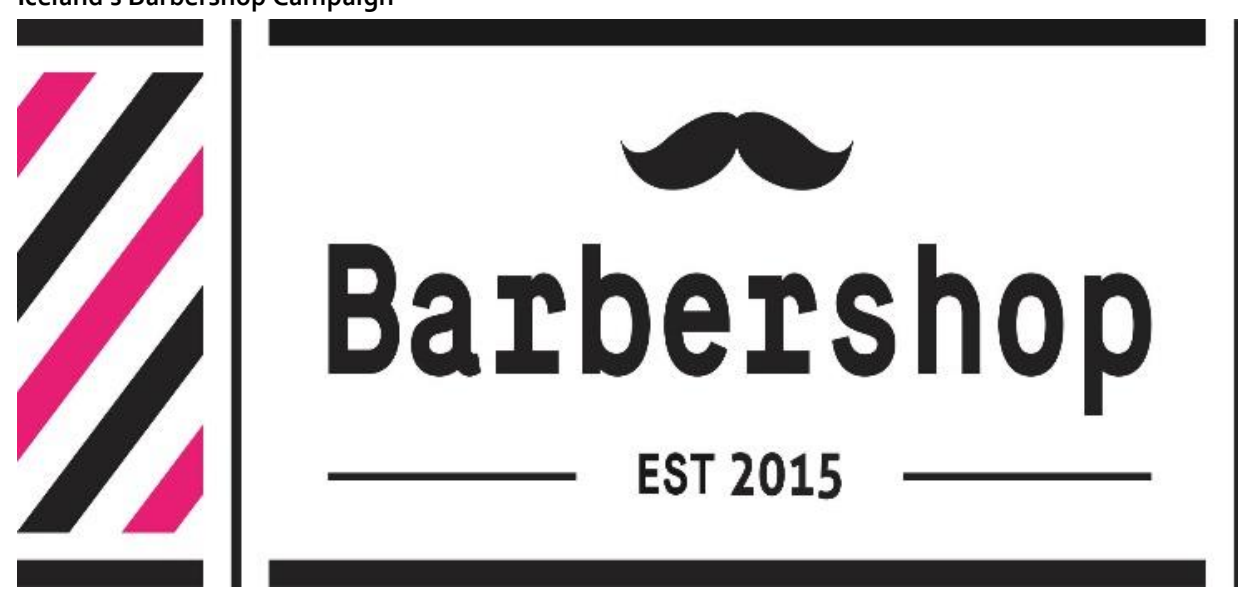

Note: The Icelandic Barbershop campaign is about rallying men and boys to commit to upholding gender equality and changing the discourse among their peers to build momentum for gender equality. It seeks innovative ways for men to mobilize and motivate other men to address discriminatory stereotypes of femininity and masculinity.

Source: Government of Iceland.

The area of women's equality was simultaneously one of the value areas that was under attack. Several interviewees highlighted the pushback against global norms and values on women's rights, including in relation to UN resolutions and bodies set up to support the rights of women and girls, such as the CEDAW (Committee on the Elimination of Discrimination against Women), the Commission on the Status of Women (CSW), UNSCR 1325 and others. This was mentioned in multiple interviews as a key area, where, in the past, global efforts regarding the empowerment of women had been concentrated on heightening standards, and the challenge now was simply to defend the status quo. For example, interviewees mentioned that Denmark received considerable pushback against their candidacy for the Human Rights Council due to their strong positions on women and girls' health and reproductive rights. The description of multilateral engagement and cooperation in the multilateral arena in section three elaborates on how the Nordics are experiencing pushback as well as finding new strategies to build momentum, finding new, smarter ways to build broader coalitions. 


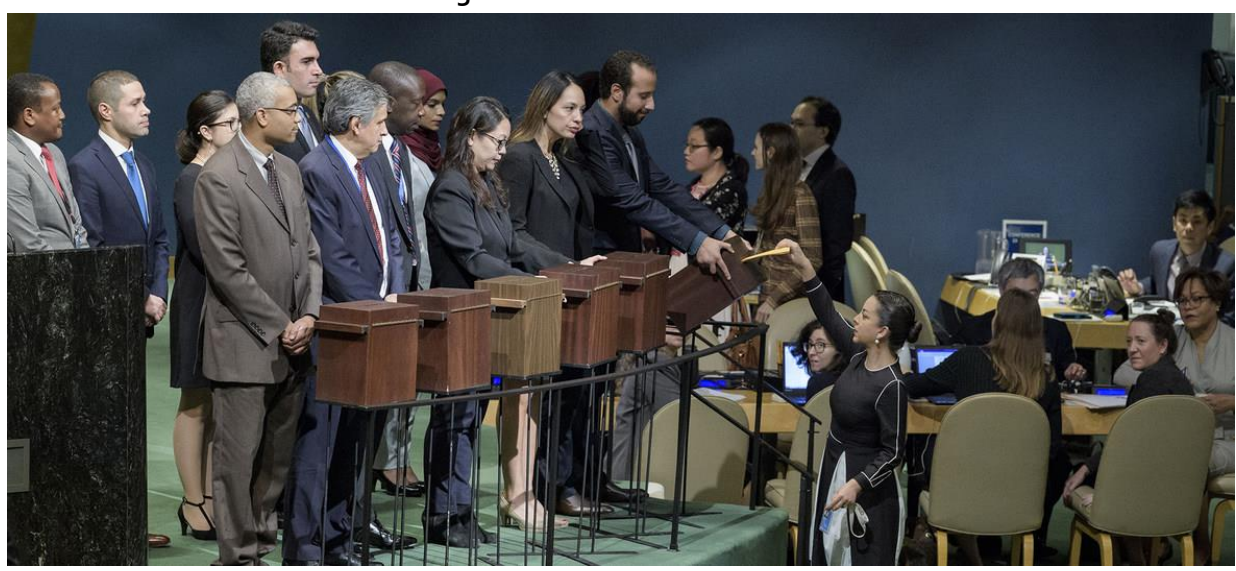

Note: Denmark won a seat on the Human Rights Council with the support and advocacy of the Nordic countries, among others. The photo shows the collection of ballots for the election of members of the Human Rights Council at the General Assembly on 12 October 2018. Denmark's seat is for the term 2020-2022. Denmark will work for "three D's" during its term: For dignity and human rights through dialogue and development.

Source: Manuel Elias/UN Photo.

Working together on Women, Peace and Security: The case of the Nordic Women Mediators

Nordic Women Mediators network (NWM) was launched in 2015 to strengthen both the access of women mediators in the Nordic countries and to support the inclusion of women in peace processes worldwide. The NWM meets annually and includes national networks, which meet more frequently. Members of the network count experienced women working within foreign affairs, mediation, peacebuilding and conflict resolution. The NWM is linked to other regional women's mediation networks and has taken the initiative to form a global network of women mediators. The NWM is highlighted in most of the National Action Plans of the Nordic countries as a success story of promoting the Women, Peace and Security agenda. In the interviews, the NWM was highlighted as a case of a Nordic forum that fostered information sharing and trust and which had potential to lead to more cooperation and collaboration. Although increased Nordic cooperation is not a declared goal of the network, the annual meetings and inherent calls for discussing issues of substance, increase Nordic cooperation. The network has not been formalized and has no outspoken advocacy role. As such, the network illustrates the duality of the Nordic appetite for working together: Members prefer an organic, bottom-up approach. A case of closer cooperation that has sprung directly out of the network was a joint workshop for South Sudanese women stakeholders as a collaboration between two Nordic countries and the African Women's network, Femwise, where network members from four Nordic countries participated in support to the South Sudanese deliberations. An important outcome of the NWM is the increased trust and social bonds among participants. For example, an interviewee and member of the NWM mentioned a recent example: "There was a day in December when suddenly I was in Nairobi having my program changed and then realizing I wanted to look into the Kenyan national dialogue (...) in one day I got all the contacts and material from [a partner organization in the NWM, red.]. I really feel that it was because of the confidence and the trust that we have gained through the Nordic Women Mediators." 


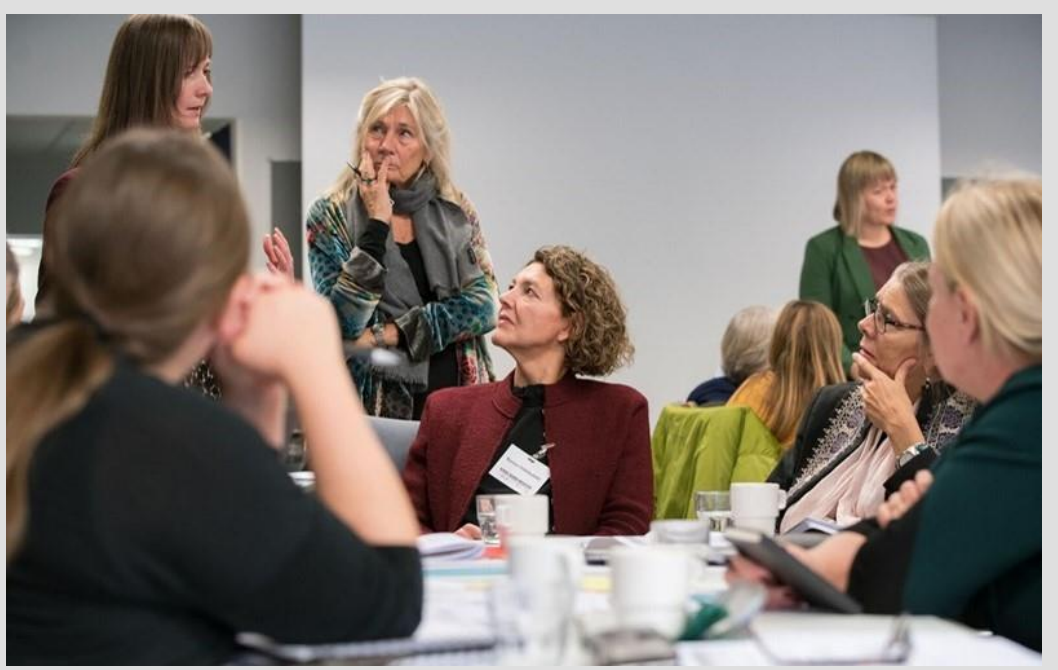

Note: Members of the Nordic Women Mediators engage in discussion at their annual meeting in Helsinki, 2017.

Source: Crisis Management Institute (CMI). Photo: Riku Isohella, CMI

Whereas mediation, as described in the section above, is part of the Nordic Peace brand but remains an area where working together is more complicated, women, peace and security and prevention are areas where further Nordic cooperation could be both possible and valuable. We therefore suggest deeper Nordic collaboration and branding in these areas, as we will come back to in the last section on recommendations.

The link between climate change and violent conflict was mentioned in several interviews, but it was not linked specifically to Nordic cooperation or the Nordic Peace brand in the interviews. Although it was beyond the scope of this report to explore this further, we strongly recommend increased attention to Nordic cooperation on combating climate change, not least due to the close links between the imminent threat of climate change and fragility. As a further exploration of the Nordic Peace brand and its practical application, the next section unpacks how the Nordics work together. 


\section{Ways of working together}

While each of the Nordics has its own distinct angle on peace and conflict resolution (and they are sometimes acutely aware of their differences), they have been working together on many levels within peace and conflict resolution; whether in the Nordic capitals or in embassies abroad in conflict-affected countries. This section presents Nordic ways of working together on peace and conflict resolution. Based on descriptions and examples given by the practitioners of how their joint Nordic work is structured, we inductively distill three degrees of Nordic integration: coordination, cooperation and collaboration. We identify conditions that facilitate integration and examine the limits and potentials to working together.

\subsection{A continuum of working together}

The Nordic foreign policies (and, thus, peace and conflict resolution) are not part of the formal Nordic structures under the Council of Ministers and the Nordic Council. As soon as we moved beyond the strictly formal level, however, people described a rich culture of working together, and there seems to be a rich culture of working together informally. From simply sharing information systematically to deep collaboration, we found that, at different levels, the Nordic ways of working together within peace and conflict resolution are multifaceted despite its informal status in official Nordic policy.

Figure 3 presents three types of working together on a continuum ranging from lessintegrated (light pink) to more-integrated (red) approaches. Where coordination mainly involved information sharing, cooperation is characterized by a degree of division of labour among actors, each responsible for solving a certain part of a joint challenge. Collaboration, the most integrated form of working together, is a coordinated, synchronous activity resulting from continued attempts at constructing and maintaining a shared conception of a problem and to come up with a joint solution to that problem. Knowledge is thus formed in a joint process and action is based on this joint picture.

Figure 3: Ways of working together

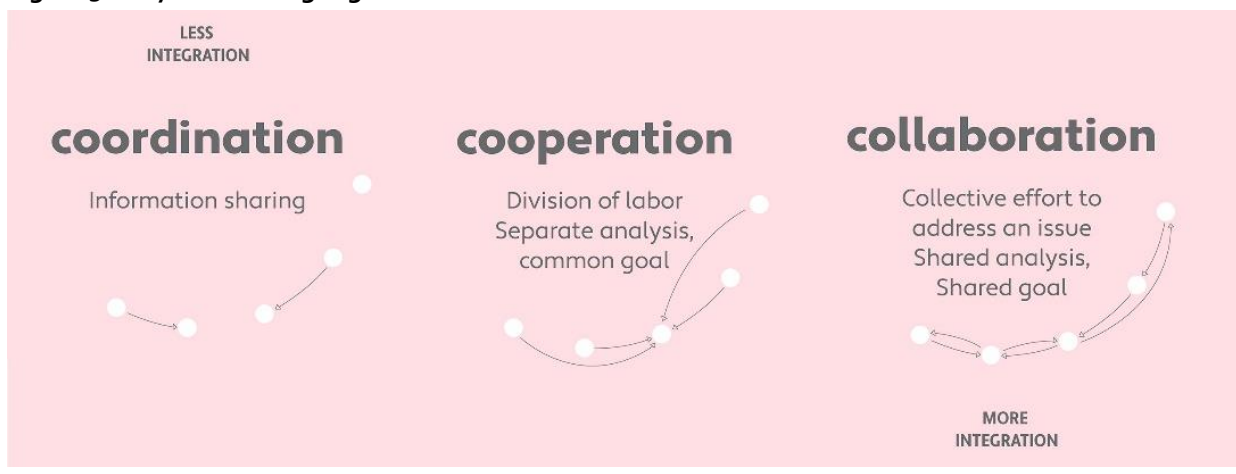


It is important to note that these categories are ideal types on a continuum, meaning that there are many activities that do not practically fall into a precise category, possibly figuring in-between. It is also important to emphasize that the three forms of working together can co-exist in related fields. In an embassy in a conflict-affected state, for example, there could be coordination among staff in one area, say with regards to political dialogue, meaning that the information-sharing mechanisms were in place and efforts to avoid overlap were taken. Meanwhile, staff could be cooperating on civil society support in that several Nordics would support civil society, with common aims among the Nordics, but funding going to different districts or different organizations. While they would all be organizations working within the area of human rights, one Nordic would mainly support peacebuilding and transitional justice, another be strongest on the inclusion of women, while a third would be focused on land and property rights. Lastly, in a program to support elections and democratic governance, the Nordics might work together to pool funds, formulate joint programs and represent each other, having a completely integrated approach in an area where interests were aligned and the advantages of pooling resources are high.

\subsubsection{Coordination}

Coordination and information sharing develops naturally among the Nordics at all levels, be it between politicians, bureaucrats, civil society actors working on peace in the Nordic countries; in other capitals with a large concentration of actors working with peace, such as Brussels, Geneva, New York and Washington DC; and at the country level, wherever there is more than one Nordic embassy.

\section{Example of Coordination: The Nordic Five $\left(\mathrm{N}_{5}\right)$ Meetings}

A good example of a successful coordination mechanism on peace and conflict is the high-level structure of the Nordic Five ( $\mathrm{N}_{5}$ ) where the Ministers of Foreign Affairs discuss foreign and security policy. The areas are not part of the official Nordic ministerial coordination, meaning that policy discussions are informal. The meetings have a focus on information sharing and discussion of current foreign policy topics and mainly stay at a coordination level. The Nordic Five $\left(\mathrm{N}_{5}\right)$ and the informal Nordic-Baltic coordination (NB8) are examples of coordination, which have not evolved into more integrated formats, nor would we expect them to; unless a political decision was made to change the status of Nordic foreign policy. At the local level, embassies from the Nordic countries engage in a systematic coordination; a typical format is ambassadors' meetings, where Nordic ambassadors meet, share insights and strategize, in some contexts weekly or monthly. 


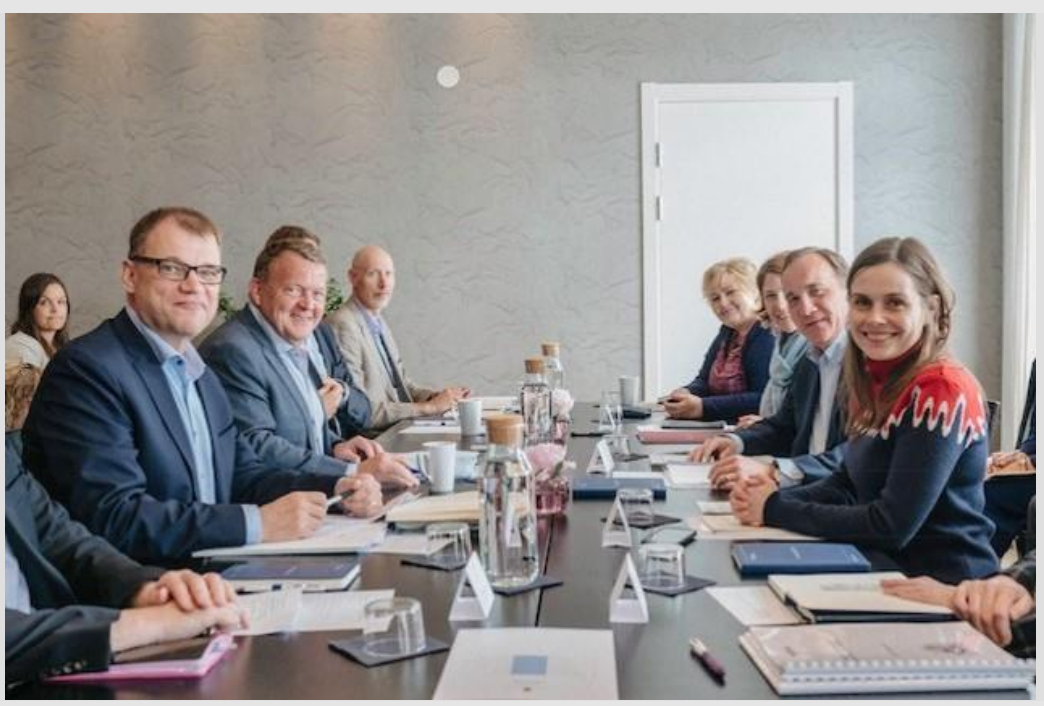

Note:

Nordic foreign and security policy is not formally coordinated and therefore not included in the structure of the Nordic Council of Ministers. Nonetheless, the Nordic prime ministers and foreign ministers meet regularly to discuss current issues. Here, the prime ministers are gathered at their informal summer meeting in Örnsköldsvik, Sweden.

Source: Victor Svedberg, Swedish Government Offices.

One activity on the margins of coordination and moving towards cooperation is the issuing of joint statements. At the global level, the Nordics often issue joint statements in the UN. A recent example of a joint $\mathrm{N}_{5}$ statement was on Iran in October 2018, signaling joint Nordic condemnation of the assassination plot in Denmark by an Iranian intelligence agency and "deploring any threat to Nordic security". One interviewee specifically emphasized the joint Nordic statement on Iran as an example of how Nordics are inching closer to each other and to more integration, even at the highest levels of foreign and security policy. 


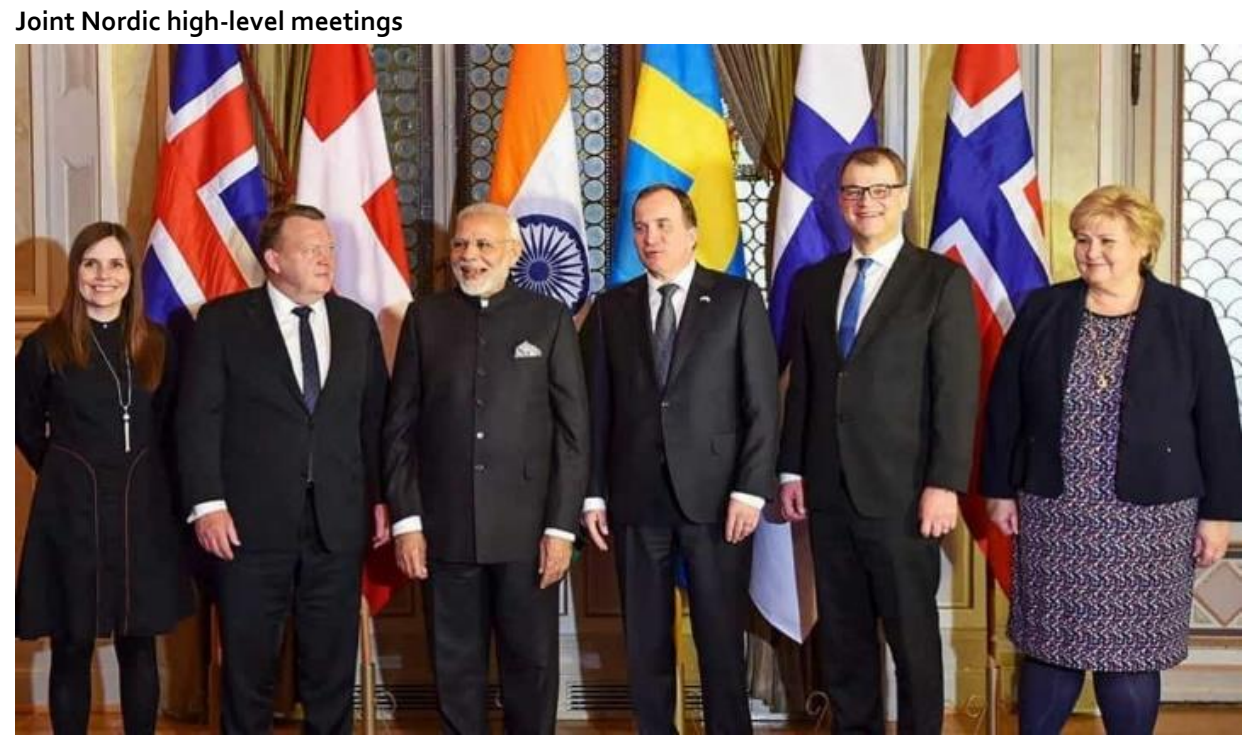

Note: Although the Nordics only coordinate informally, joint meetings with heads of state offer a way for them to gain access and leverage as a group. Here, the Nordic prime ministers meet with Indian Prime Minister Narendra Modi in Stockholm in April 2018. Organizing one joint meeting proved the only feasible way for all of the Nordics to meet with Modi on his trip to Europe. Similarly, the Nordic prime ministers met jointly with US President Barack Obama in 2016.

\subsubsection{Cooperation}

Cooperation entails a slightly deeper level of engagement and commitment to working together, where actors not only share information but also engage in finding joint solutions. The Nordics cooperate on many different levels. Examples at the multilateral and regional levels typically take the form of joint campaigns or joint initiatives, examples at country level are typically areas in which the Nordics have similar values and support certain sectors within peace and conflict resolution, such as civil society initiatives, where cooperation ensures that the Nordics support different angles on the same issue.

\section{Example of cooperation: The multilateral level}

All of the Nordic countries have been strong advocates of the rules-based international order and human rights, and they have invested in multilateral cooperation. Being small, open democracies, the Nordic interest in furthering the values of rules-based democratic coexistence has been consistent. Many emphasized the UN as a vehicle for promoting shared values in the global arena; one interviewee even stated that the UN is "the best example of how Nordic cooperation - and Nordic cooperation alone - can move mountains. It is just amazing what has been done. The cooperation there is so close." Here, the format is typically coalitions in the model "One Nordic country takes the lead, but with the support of the other Nordics." Examples such as the recent Security Council campaign of Sweden or the Human Rights Council Campaign of Denmark were models, where all of the Nordics would rally behind a priority and strategize and work actively to support the common goal of winning a Nordic seat. Several interviews mentioned the failed Nordic Security Council campaign in 2012 as a point where the Nordics realized that "not everyone cares for Nordic self-righteousness." We identified this 
as a more general trend of building stronger and wider coalitions, which will be further elaborated in the section on "Non-exclusive Nordic cooperation".

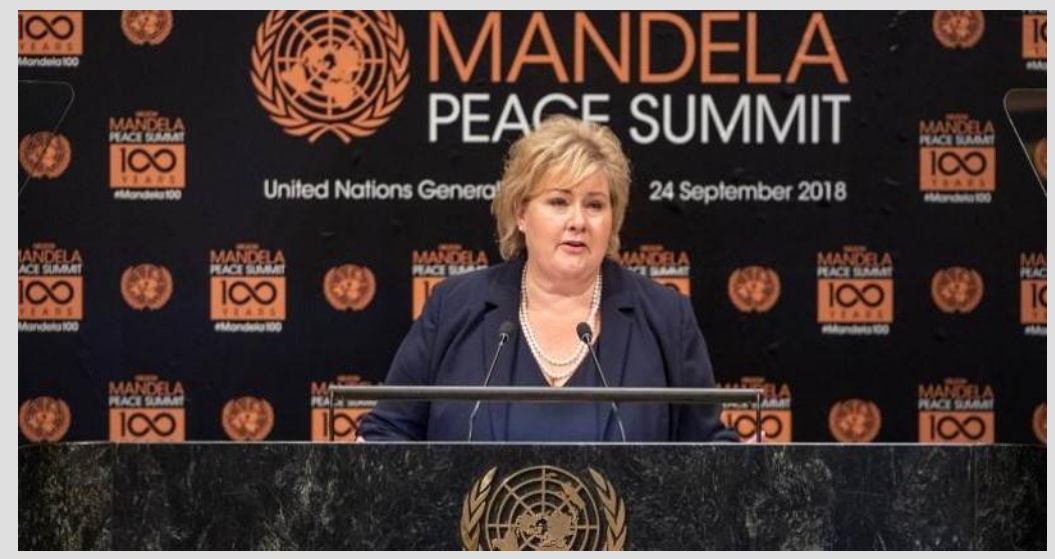

Note: In a joint Nordic statement at the Mandela Peace Summit in September 2018, Norwegian Prime Minister Erna Solberg spoke on behalf of the Nordic countries. She stated that the end of the Cold War "marked the beginning of Nordic engagement in conflict resolution. It has since become a cornerstone of Norwegian and Nordic foreign policy. For over 25 years all the Nordic countries have been engaged in efforts to resolve conflicts around the world. "Nordic common positions and strategizing is common practice in the United Nations. More and more, the Nordics are also engaging in Non-exclusive cooperation.

Source: United Nations

\subsubsection{Collaboration}

Collaboration involves an even deeper layer of information sharing and division of labor to sharing joint analysis and letting that analysis influence decision making and action. Collaboration thus involves a different degree of knowledge exchange altogether, which essentially entails shaping understanding and analysis of a situation together. The joint analysis also allows for defining the nature of challenges together, rather than separately. Deeper levels of trust and openness are required for this level of collaboration to exist as well as routinized mechanisms of coordination being in place already.

\section{Example of collaboration: Nordic integration in Kabul}

Several interviews across the Nordic countries mentioned Afghanistan as a good example of a conflict setting in which Nordic work has been integrated well beyond mere ad hoc information sharing and cooperation. The scope and scale of the Nordics working together in Afghanistan is far-reaching and was presented by many as a best practice of what constructive collaboration looks like.

Together, the Nordics are among the five largest bilateral donors in Afghanistan. The sheer volume of aid alone gives the joint Nordic voice considerable leverage politically. Besides increasing access, working closely together has allowed the Nordics to push common joint agendas with amplified influence. For example, in relation to current attempts at reaching a new political settlement among 
the conflicting parties and political players in Afghanistan, the Nordics have used their seat at the table to pursue joint Nordic priorities.

The collaboration in Afghanistan is an example of a very integrated approach. The Nordics operate as the NordicPlus, counting the Nordics and the Netherlands (only including Iceland on development issues). NordicPlus is an entity with a rotating chairmanship and, since 2018, a joint work plan. The NordicPlus-community shares analysis and sometimes carries out joint analysis. Uniquely, the group has divided central tasks among them, designating one with the responsibility for elections, another with responsibility for anti-corruption efforts etc. The trust among partners is so deep that many of the key area responsibilities rotate, so the lead on various issues regarding both political and development engagement shifts from one to the next with biannual or annual chairmanship. This demonstrates coherence and trust in both a joint understanding of challenges and goals as well as confidence in each other's equal ability to address them. Important for the Nordic example in Afghanistan is also that it is able to accommodate a variety of different bilateral Nordic relationships. For example, the Norwegians and Danes share a colocated embassy complex including staff accommodation, which has led to a high degree of integration; different constellations of countries sometimes jointly fund initiatives bilaterally; and Iceland, which has no official representative deployed to Afghanistan, has delegated responsibility to an Icelandic officer seconded to an international organization, who is involved in the coordination of Nordic development efforts. In addition, each Nordic country has certain engagements, which are more sensitive and which the others are only involved in where relevant. The sensitivity to leave room for a certain division of labor was therefore highlighted as a strength. The flexible Nordic arrangement has generally allowed for varying degrees of integration to coexist within the group as well as for integration to grow deeper in an organic manner when relevant and possible.

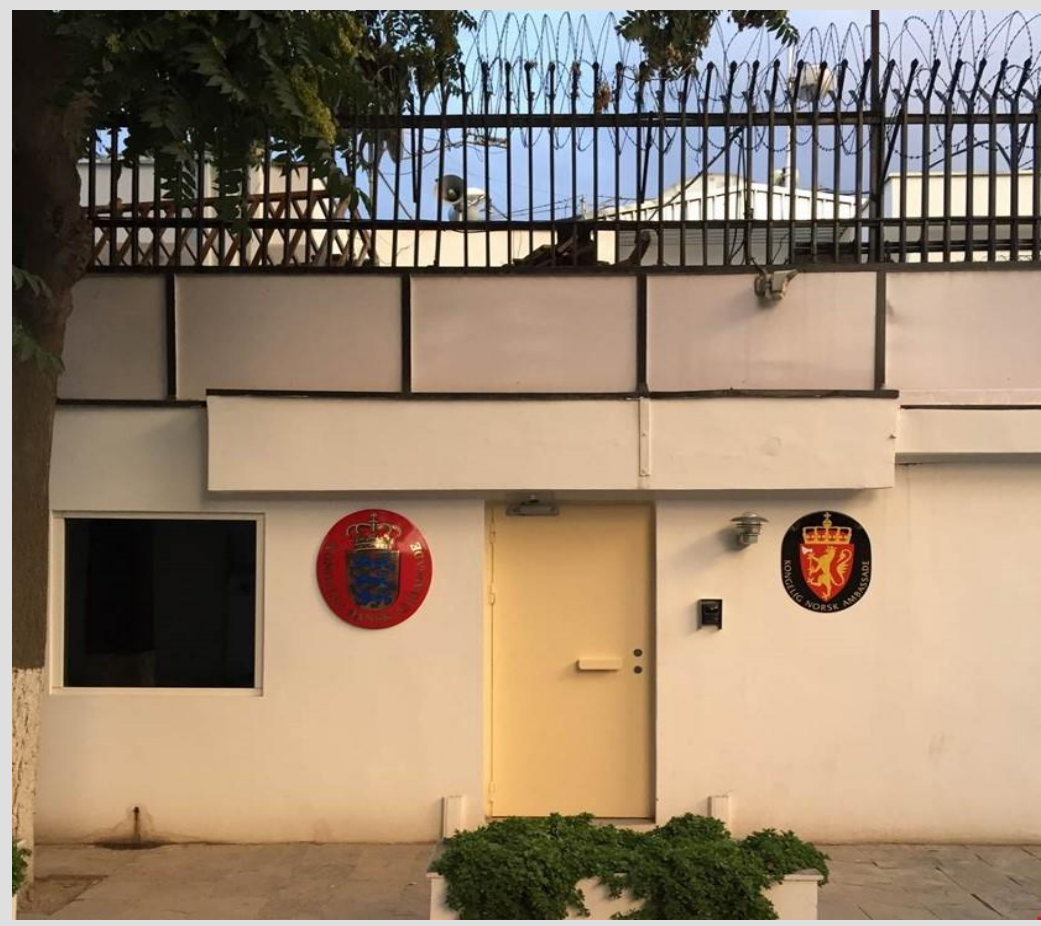

Note: The Nordic countries work closely together in Afghanistan. The picture shows the entrance to the shared Danish-Norwegian Embassy in Kabul, Afghanistan

Source: Danish Ministry of Foreign Affairs 


\subsection{Conditions that shape integration}

Parallel to the policy realm, there is a wide range of practical collaboration at all levels. This type of collaboration includes embassy colocation, joint visa-application processing and practical support among the Nordics. For example, there are regular, institutionalized meetings between the heads of IT, heads of property management, legal departments etc. among the Nordic countries' foreign ministries and other relevant actors to facilitate the coordination in these areas.

Colocation of diplomatic missions

The Nordics have been practicing the colocation of diplomatic missions for decades. There are a variety of models of colocation among the more than 20 locations where two or more Nordic embassies or representations are colocated. An example of a legacy effort to collocate is the joint Nordic embassy complex in Berlin, where the Nordic countries bought a property together and each built an office. The political focus on colocation has increased in the past decade. Starting with the Stoltenberg Report in 2009, the Gade-Birker Report in 2012 and a joint declaration from the Nordic Ministers in 2012, colocation as a goal in itself became a specific priority theme for the Nordic Council of Ministers, the main reasons cited being to increase cost-efficiency and policy influence. Particular projects include embassies in Yangon, Dhaka, Islamabad and Hanoi, and joint solutions in Europe and North America are also being pursued.

\subsubsection{The relationship between practical integration and policy integration}

In conflict-affected countries, colocation and other forms of practical cooperation can be of considerable significance for the integration of policy. Interviewees highlighted reasons for colocation in conflict areas, such as practicality, efficiency, resource concerns and security. Many of the challenges of colocation were related to technical barriers between the Nordic countries, for example related to incompatibility in administrative, legal, security and IT systems. Interviewees explained how these could be considerable due to the different rules and approaches among the Nordic countries. The interviews made clear that when there was a clear signal from the political to the working levels regarding the political priority of a colocation project, the incentives to overcome the many practical and technical challenges were higher. The 2012 Ministers' Declaration, mentioning specific embassies, was cited as a good example of this. Although important headway had been made in Kabul, Dhaka and Yangon, for example, there was clearly some way to go in implementing this agenda fully and further political commitment might be key to overcoming implementation challenges.

Our interviews gave the impression that practical measures such as colocation seem to lead to greater policy integration. Working and living side by side with a group of people over time provides a basis for increased information sharing and, where possible, deeper collaboration. A range of interviewees referred to the Nordic presence in Kabul as an example of a strongly integrated Nordic effort, where colocation was a contributing factor to deepening policy collaboration (see the example above for an elaboration of this). Likewise, the Nordic House in Yangon, which houses the Danish, Norwegian, Swedish and Finnish embassies, was mentioned as a case 
where colocation also shaped common policies and projects. A reinforcing condition that was noted in addition to colocation was the fact that the security situation in conflict settings restrains mobility, and colocation therefore has an even stronger impact than probably would be the case in a non-conflict environment. As one interviewee mentioned, this generated a "camp atmosphere" among the staff. Our findings thus suggest that practical measures such as colocation often shape increased policy integration, and especially in conflict-affected countries.

Besides colocation, a pivotal condition shaping and encouraging Nordic cooperation in conflict-affected countries is like-mindedness in terms of both substance and form; that is, shared values and similar ways of working, which will be examined more closely in the following section. 


\section{Benefits and challenges of working together}

This section takes stock of the benefits and challenges of working together and the appetite for deepening collaboration.

\subsection{Benefits of working together}

Based on our interviews, this section identifies the advantages and potentials of cooperating and coordinating amongst Nordic countries when it comes to peace and conflict resolution efforts in terms of increasing impact and gaining extended information as well as the benefits related to similar working cultures, values and trust that foster close, straightforward cooperation.

The Nordic family celebrating Christmas

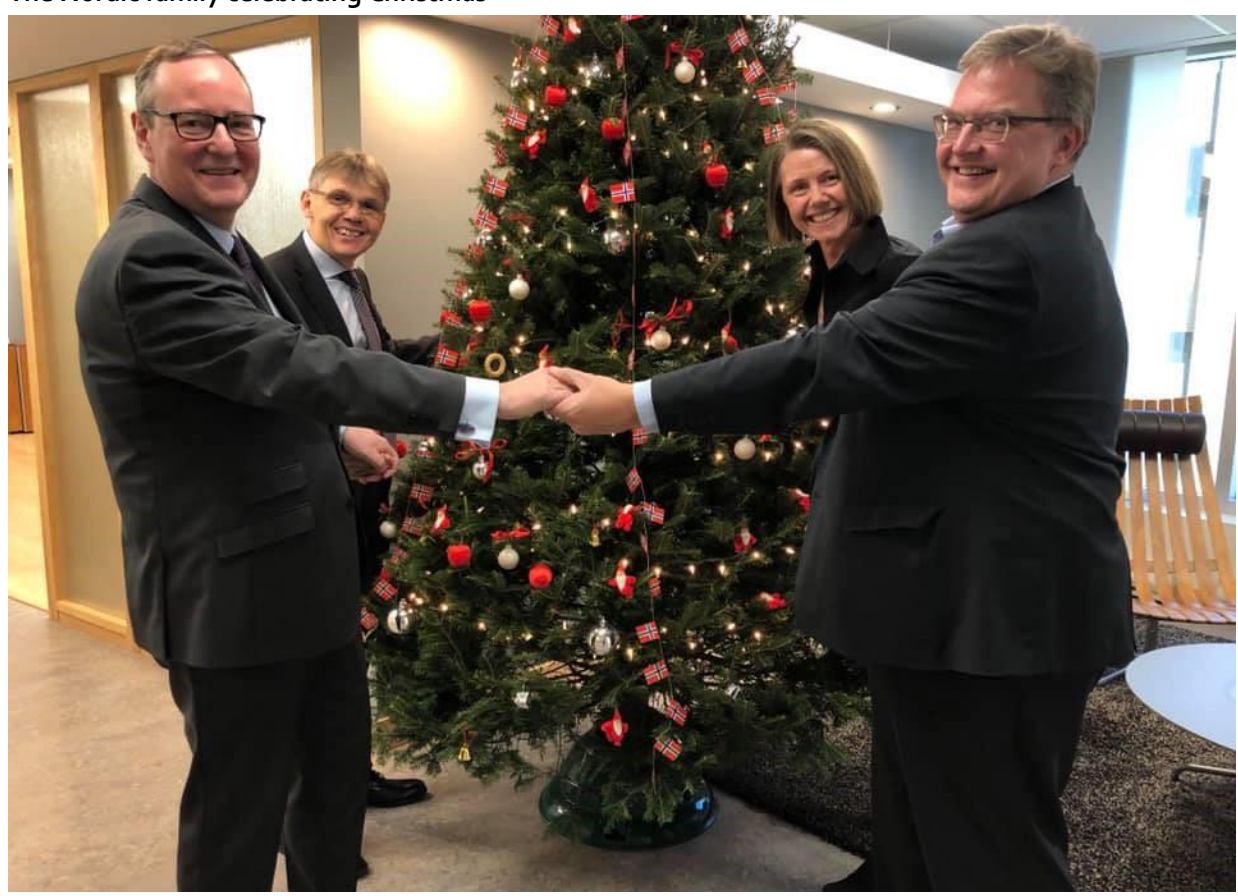

Note: Ambassadors of Denmark, Finland, Iceland and Norway to Canada celebrate Christmas in Ottawa, 2018. There is a strong tradition of Nordic ambassadors working together. When a Nordic ambassador takes up a new post, the first people she will typically call are her Nordic counterparts, according to several interviewees. The benefits of Nordics working together often spring from mutual trust and cultural affinity both in terms of values and ways of working.

Source: Thomas Winkler. 


\subsubsection{Increasing impact}

Many of the interviewees emphasized how working together often increases the impact of different Nordic efforts and multiplies the power and access of the particular countries. Using a consistent, common voice, the level of access to policy fora potentially increases greatly. The Nordics speaking with one voice or attending meetings together gives a completely different leverage and "brings us into the major leagues" as one interviewee put it. The advantage in terms of access and leverage was a general lesson mentioned by interviewees speaking about different Nordic engagement across four continents. For example, the Nordic ambassadors often work together in a given context, go on field visits together or push for shared political agendas, thereby amplifying their individual voices. One ambassador tellingly stated how "we have a Nordic brand that we could possibly use more. It gives us a good profile when we go out together and perform together. In addition visiting different counties together generates good press coverage and awareness of us."

\subsubsection{Deeper information and analysis}

Internally among the Nordics, the level of analytical understanding being potentially heightened when resources are pooled was also mentioned in interviews. It was stressed how the Nordic countries often act as each other's eyes and ears in different fora where the other Nordic countries are not represented. One example was in relation to key multilateral fora; since Norway is not part of the EU, while Sweden and Finland are not part of NATO, the Nordics benefit from information sharing from these organizations both at the headquarter and country levels. Likewise, in many contexts, some Nordic countries may have a larger representation than others. One example cited in this regard is how Finland has its largest embassy in Russia, and the remaining Nordic countries benefit greatly from information sharing and analysis due to the comprehensive Finnish understanding of the context.

\subsubsection{Similar working cultures}

Another oft-cited advantage of was the similar working culture and straightforward communication between the Nordics. Nordic ways of working are driven by pragmatic like-mindedness and practical solutions. The shared values, working culture and approaches make working together easy. One interviewee stressed how "there's something about the way we (the Nordics) approach things, we're quite open and direct, we don't spend a long time on introductions and preliminary talk. It's straight to the heart of the matter." This similar working culture stimulated close cooperation that is both straightforward, easy and time-efficient. Several interviewees therefore also described their working together as "natural" or "organic", emerging out of similar working cultures and mindsets rather than larger strategic considerations or formal structures and the strong preference for letting joint work emerge in this way. Apart from a more direct and pragmatic approach, a central aspect of the Nordic working culture that also 
relates to the basic trust described below is a culture of resolving conflicts. One interviewee tellingly described a situation in which Nordic cooperation had been attempted but failed due to major disagreements: "but then again, the advantage is that even in such a situation, where it's fair to say that we really disagreed - both regarding substance and the process - even then we could still talk about it."

\subsubsection{Trust}

One of the most central advantages to working together around sensitive issues such as peace and conflict resolution might be the high level of trust among the Nordic countries and the deep understanding of "having each other's backs". Several interviewees stressed how this obviously also related to personal connections and that some Nordic colleagues are more like-minded than others on a personal level. Nevertheless, the shared history, language, culture and a general sense of "being part of the Nordic family", as was stressed in many interviewees, promote a high sense of trust among the representatives of the Nordic countries. This trust enables information sharing and close cooperation. As one interviewee highlighted, "You can always ask your Nordic colleague about something and know that it won't be leaked to the press (...) there's a basic trust. And with the Nordic colleagues you can be much more open than you can with other colleagues."

\subsubsection{Shared values}

Finally, a recurring topic in the interviews was the shared values and like-mindedness of the Nordic countries, which enable strong cooperation by virtue of having a shared interest in promoting similar values such as rule of law, gender equality, the inclusion of civil society and international cooperation. For example, one interviewee stated that "on the big questions there's a common foundation rooted in the common values: support for democracy, rule of law and peaceful conflict resolution." Likewise, another interviewee explained how "in Nordic statements we can go further" when comparing Nordic statements on women, peace and security with EU statements on the subject matter. The thematic of the commonality of values is discussed at length in the section on the Nordic Peace brand.

\subsection{Challenges of working together}

Besides the benefits of working together amongst the Nordics, there are also drawbacks and challenges that render cooperation difficult or even unwanted in certain areas. These challenges include issues of competition, confidentiality in mediation, diverging systems and setups, as well as varying budgets, which are addressed in the following.

One of the challenges of working together is the potential competition that may occur in areas where two or more countries have an interest in being responsible for a particular process or policy agenda or want to gain visibility or take political credit in relation 
to a peace process. The competition issue was a recurring subject in the interviews, many interviewees emphasizing the importance of not competing.

Certain policy areas lend themselves more to competition, such as that of peace mediation, narrowly defined. In many interviews, the countries involved in mediation voiced concerns and reservations in terms of the other Nordic countries' efforts in the area as well as concerns with regards to working together. It is obvious and legitimate why a country that has invested years of funding on mediation wants credit: there is considerable political capital to be gained from being the primary broker of a peace deal, externally and to the taxpayers at home. Ironically, representatives from several different countries noted how certain other Nordic neighbors sought the "limelight and green lawns," in other words actively seeking the public credit for peace efforts, more than their own country did. Several interviewees across the Nordic countries mentioned Colombia as a case where there had been good cooperation on civil society and gender equality projects, but where several parties had also expressed concerns about other countries taking credit for the successful peace agreement rather than sharing recognition. One interviewee expressed how this illustrates "the potential problems when you have Nordic cooperation: Who takes the credit for things? Are we able to all take the credit together? Or would the temptation to take the credit yourself be too great?"

However, several interviewees also stressed that it was not necessarily competition as such that generated challenges regarding cooperation on peace processes, but rather the fact that the field of peace and reconciliation is not always geared to close collaboration of any kind due to the often confidential and discrete nature of the endeavour. One interviewee refers to how "It can sometimes look more like a competition than it really is. Sometimes it's related more to local sensitivity, local ownership; you can't always disclose what you're doing. You might want to do that yourself, but if the parties to the conflict say that this cannot be disclosed, what can you do?" Certain areas are simply "off limits".

At the same time, as more countries get involved in the area, the sharing of information or division of labour could become of common interest. While stressing the importance of confidentiality and how it challenges the Nordic cooperation on peace mediation, the actors working on peace negotiations with whom we spoke also identified areas where Nordic efforts in mediation more broadly defined could be more coordinated. For example, one interviewee mentioned how Norway, in a particular case, had experienced challenges related to being a lead facilitator and monitoring a ceasefire agreement at the same time. A ceasefire agreement, which entails a pause or stop to using armed force among conflicting parties, has guarantors, or monitors, who track possible violations to the agreement. Being the observer and "judge" of a ceasefire and simultaneously having to engage in the mediation of peace - typically a more neutral role - is a difficult balancing act for anyone. In such cases, other Nordic countries could assume the responsibility for monitoring the ceasefire. In the specific case, a joint monitoring mechanism among the Nordics had indeed been set up and had been successful, according to several interviews. Likewise, the Nordic Women Mediators is an example of the potential usefulness of sharing experiences from previous cases and developing ideas of, for example, further integrating tracks 1, 2 and 3 diplomatic efforts - combining the different comparative advantages of the Nordic countries in peace and conflict resolution. 
Another limitation to working together which came up in many of the interviews, especially the ones concentrating on practical, administrative, logistical and legal forms of working together, was that the respective Nordic countries have relatively different systems, set-ups and rules that often contradict each other. In one context, for example, there were plans to colocate the Danish and Icelandic representations, but diverging rules on the size requirements for office space prevented the colocation.

In addition to diverging systems as a challenge to working together, major differences in budgets for peace and conflict resolution work sometimes also hamper what is possible. Whereas the prioritization of resource effectiveness can sometimes facilitate greater collaboration, the substantial spending cuts in some of the Nordic countries' foreign policy and development portfolios has challenged opportunities for joint projects. Notably, unprompted by us, representatives from all of the other Nordic countries, noted in one way or another how the substantial cuts made to the budget of the Danish MFA and on development aid, including cuts to personnel, had consequences for the opportunities for working together, since they created significant limitations to what could be done and by whom.

\subsection{Appetite for further integration}

With these potential benefits and challenges in mind, is deeper Nordic collaboration necessary and warranted? In the interviews, we took stock of the general appetite on further Nordic integration amongst the representatives of the Nordic countries and their closest partners. We found three general tendencies: There seemed to be a general sense that Nordic cooperation is "invaluable" and that its often organic way of emerging from like-mindedness was recognized widely. There was a sensitivity that due to its organic nature, Nordic cooperation is often taken for granted and that this could backfire in some instances. Most importantly, there was a general appetite for further and deeper collaboration.

Importantly, many interviewees mentioned the shifts in the global geopolitical landscape, which are affecting the immediate Nordic environment. As one interviewee put it: "We had a period where everyone thought we would all live in peace together. That's not the case anymore." Many interviewees saw the growing geopolitical insecurity as a strong motivation to increase and strengthen Nordic cooperation in a number of different areas. One interviewee stated that in light of the increasing pressure on multilateralism and international law, "Nordic cooperation has become more important than before, and the uncertainties and speed of everything are perhaps pushing the Nordic countries closer together than earlier." Interviewees also mentioned how fragmentation within the EU has meant that the Nordic member states are now aligned in more areas than they used to be. However, many interviewees interestingly emphasized two caveats regarding further Nordic cooperation: First, they pointed out the importance of engaging with other, less like-minded countries than the Nordics, both to avoid forming blocks in multilateral institutions and to avoid being seen as a single homogenous group that risks alienating others with a 
morally superior approach. Here, different variations of nonexclusive cooperation are possible, as described in the section on this in the recommendations section below. Second, several interviewees stressed that one of the major strengths of Nordic cooperation was its informal, ad hoc nature. Conversely, many examples of successful integration retrospectively related success to the policy priority given to an area, which led to systematization and re-organization. Based on our analysis, we identify two substantive areas where the appetite for further collaboration seems to be considerable. These are specified below. 


\section{Recommendations}

This section points to areas where we observe opportunities to broaden and deepen Nordic alignment: preventive diplomacy and women peace and security. Moreover, we identify a new trend of nonexclusive Nordic cooperation, where the Nordics work together along with other regional or global stakeholders. Finally, we formulate specific policy recommendations based on the findings of the report.

\subsection{Deepening and broadening the Nordic Peace brand}

One area where the Nordics could work together more closely is in the area of prevention. Prevention has come to the forefront of the international agenda. Across the board among member states in the UN, the UN Security Council and the leadership of big multilateral organizations, there is agreement on a need for better thinking about prevention; specifically exemplified by the innovative joint report by the World Bank and the UN Pathways for Peace (2018). Despite the fact that preventive diplomacy has regained attention and has become a "buzzword", it still lacks substance. Strong advocates who have a comparative advantage to fill out this substantive gap, including the Nordics, could play a significant role in shaping the global agenda. The Nordic approaches to civil society support abroad, including rights-based, long-term and inclusive engagements, foster trust and contextual understanding and thus provide a basis for heightened sensitivity to foresee, prevent and resolve conflict. The Nordics already have a tradition of conflict prevention and preventive diplomacy, each in their distinct ways, but further thinking about possible joint efforts to support prevention, both at the policy level and on the ground, seems to be welcome. Not least as resources are under pressure, the necessity of pooling efforts is apparent. The most imminent threat to life on earth is climate change. In light of the close link between conflict, fragility and the threat of climate change, a key area of further exploration for Nordic preventive diplomacy is to take a much stronger leadership role in the fight against climate change; internally becoming a $\mathrm{CO}_{2}$-neutral region and externally fighting for global action to speed up.

The women, peace and security agenda is another area where further cooperation and alignment is both possible and valuable and is one of the areas with the strongest policy affinity among the Nordic countries. As described in the sections above, all of the Nordic countries have pursued the issue of women's rights and inclusion actively as part of their agenda in the UN. This area could potentially warrant further policy integration, both because it is highly prioritized by all of the Nordics and because it is an area prone to cooperation and a division of labour whereby each Nordic country has particular comparative advantages. The fundamental insight that gender equality and the rights of women are obligations as well as necessary conditions for long term 
peace, security and development is central to the Nordic democratic model and should have a central place in any reformulation of the Nordic Peace brand. Prevention and women, peace and security are two areas, which are currently garnering increased attention and within which the Nordics all have a more or less strong profile, both separately and together. They are both areas with a high degree of value alignment but which at the same time are broad enough that the Nordics have found distinct profiles within them. Other related areas, which share these same traits of commonality and breadth include human rights and other aspects of inclusion.

Besides these substantive areas of further joint effort, we also want to highlight ways of working together that can serve as inspiration for future engagement. As described in earlier sections, colocation of Nordic embassies is a practical way of working together, which fosters deeper integration among the Nordics. Colocation is already a key component in Nordic strategies, but implementation could be further supported. Another approach with potential is establishing Nordic networks as a constructive way of letting Nordic collaboration deepen where possible. Starting pilot networks within a peace and conflict resolution might be a cost-efficient way to foster Nordic cross-fertilization without heavy-handed formalization or increased bureaucracy. The Nordic Women Mediators network is an example of such a network, which provides a platform for informal ways of working together; its key goal is to build trust among members, who can then mobilize this trust when needed and cooperate where relevant. Moreover, the network has recently reached out to other regional women mediation networks to consider the possibility of establishing a global network of female mediators. This is very much in line with another common trend that we have identified: that Nordic cooperation occurs less and less in an exclusive Nordic circle but that it is both strategic and valuable to build broader coalitions across the globe to promote certain priorities.

\subsection{Non-exclusive Nordic Cooperation}

Interestingly, much Nordic cooperation occurs not in an exclusively Nordic context but rather with one or several Nordic countries together with other countries, be they other European countries or countries from the Global South. There are different models of such nonexclusive Nordic cooperation. One entails the close Nordic cooperation adding one or a few other like-minded countries, as exemplified by the NordicPlus in Afghanistan with the inclusion of the Netherlands (see box on Nordic integration in Kabul). Likewise, the Nordics engage in close cooperation with the Baltic countries on many different issues and in many different settings, for example on the women, peace and security agenda. Another model implies broader coalitions with a particular thematic focus, not necessarily with all or even more than one Nordic country visible but with the Nordics supporting the cause behind the scenes. Many interviewees formulated a distinction between a "classic Nordic" brand or block mentality of pushing hard for certain norms as opposed to newer, more innovative and inclusive ways of working. Due to the changing dynamics in the world and the global pushback against elites and global governance, there is a tendency that the Nordics - not just in the UN but globally - are seeking 
broader coalitions that can amplify the Nordic values, but with greater legitimacy. Several interviewees mentioned the need to think creatively about coalitions in the model "One Nordic country takes the lead, but with the support of the other Nordics". One example mentioned by interviewees included an $\mathrm{R}_{2} \mathrm{P}$ focal point initiative, which was led jointly by Denmark, Ghana and Costa Rica, but with silent support from the other Nordics, as one interviewee commented: "this case of $\mathrm{R}_{2} \mathrm{P}$ is a really good example of how you can expand the Nordic brand." Another example is a "Group of Friends of Mediation" initiative launched to promote the use of mediation in peaceful solutions to conflict, initiated by Finland and Turkey. In this way, Nordic cooperation should not be considered an exclusive arena of cooperation but rather a basis of support that can be mobilized in different settings and constellations. As one interviewee stated, "less and less we believe that the Nordic circle is the demonstrable unit that does things together. Our strength is that we are so well coordinated, we speak so well together, we know what the others are doing, we support each other's initiatives, but strategically it is more important to have a cross-regional alliance than to have a Nordic alliance in public."

\section{Non-exclusive Nordic cooperation}

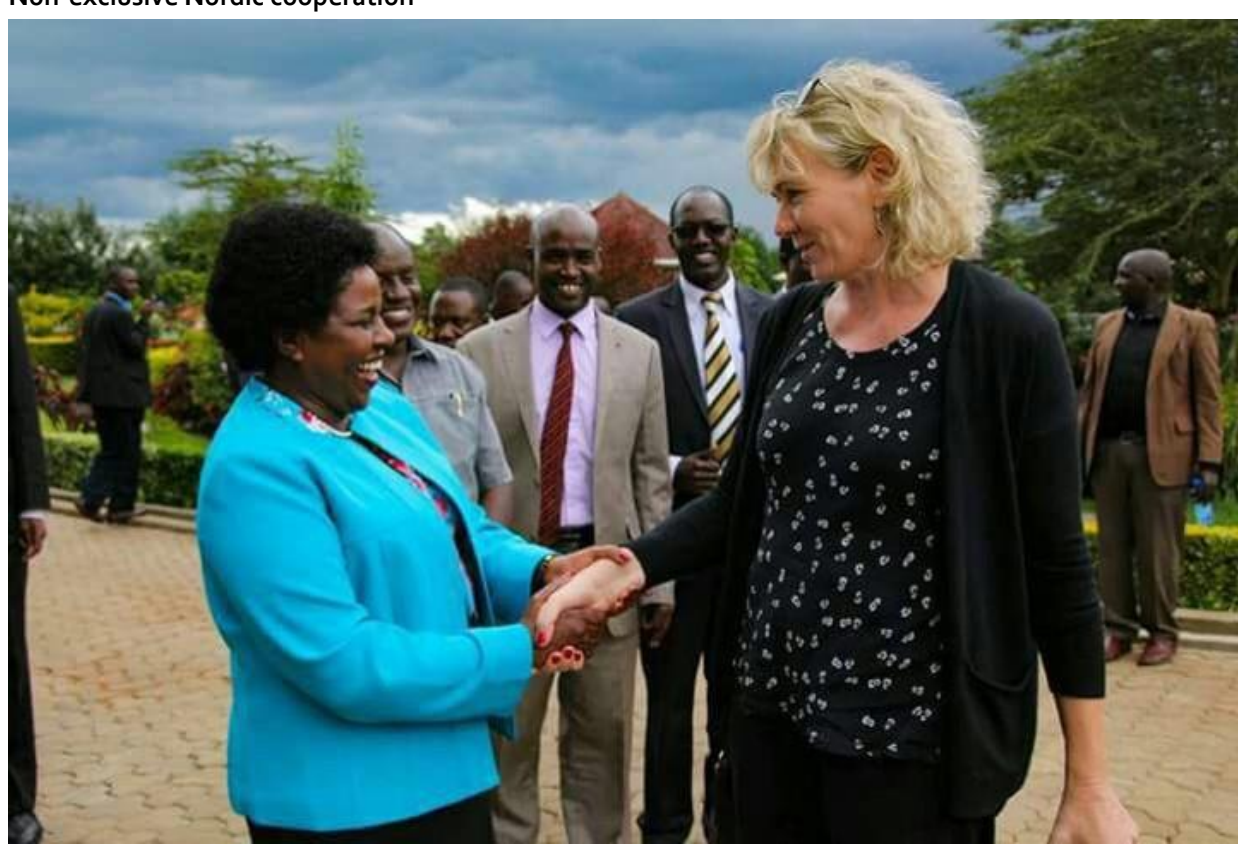

Note: The Danish Ambassador to Kenya, Mette Knudsen, shakes the hand of the Governor of Bomet County, Kenya, Joyce Laboso. Laboso is one of three women governors in Kenya's 47 counties. The picture was taken as part of a joint Nordic visit to Bomet on 8 May 2018. Due to the changing dynamics in the world and the global pushback against elites and global governance, there is a tendency that the Nordics - not just in the UN but globally - are seeking broader coalitions capable of amplifying Nordic values, but with greater legitimacy.

Source: Danish Embassy, Nairobi. 


\subsection{Policy recommendations}

Based on policy evaluations and inputs from interviews with Nordic stakeholders, we present the following recommendations regarding Nordic cooperation on peace and conflict resolution and the optimization of resources.

1. The Nordic Peace Brand

- Establish a working group to look at including the Nordic Peace brand in the general branding efforts of the Nordics, "Nordic solutions to global problems".

- Commission a vision paper by a senior expert on peace and conflict resolution from each Nordic country on the potentials and visions for strengthening the Nordic Peace brand.

- Integrate women's empowerment, civil society inclusion and preventive dialogue in in a new Nordic Peace brand.

\section{Peacebuilding}

- Convene a seminar among Nordic peace and security practitioners to look into more systematic Nordic experience sharing and learning on peacebuilding and whole-of-government approaches.

- Reinvestigate the possibility of a Joint Nordic Task Force on Stabilization - or perhaps for peacebuilding - including four components: A military component, a humanitarian component, a state-building component (including police officers, judges, prison officers and election observers) and a development assistance component, as suggested in the Stoltenberg Report in 2009 and as discussed regularly since then. ${ }^{1}$

\section{Preventive diplomacy}

- Consider establishing a Nordic Early Action Deployment Capacity that specializes in preventive diplomacy and early intervention in conflicts, drawing on the vast Nordic network of practitioners and scholars with expertise including area-specific knowledge, mediation, dialogue and conflict analysis.

- Set up a focal point team to think through a Nordic set-up for an early action mechanism among bureaucrats, practitioners and researchers.

\footnotetext{
1 The assessment in 2016 by the Nordic Council's Middle Group was that this initiative was yet to be followed up on. The description of such a mechanism here was as follows: "Stoltenberg-rapporten från 2009 föreslår bland annat att de nordiska länderna startar en insatsenhet för fredsbyggande åtgärder som består av både militär och civil expertis och som på kort varsel kan skickas till världens konfliktområden. Förslaget har sitt ursprung i de nordiska ländernas höga kompetens inom sk. multidimensional mandates, dvs. i fredsbyg-gande aktiviteter som innehåller både militära och civila insatser som t.ex. att utbilda poliser till att restaurera kulturarv eller försäkra rättssy-stemets funktion" (Nordic Council 2016).
} 
- Prioritize stronger Nordic cooperation and leadership in countering climate change; internally becoming a $\mathrm{CO}_{2}$-neutral region and externally fighting for global action to speed up.

\section{Networks and coordination}

- Convene a Nordic Peace and Conflict Summit where practitioners, policy specialists and academics working with peace and conflict resolution can share lessons learned, explore areas of working together and come up with recommendations fostered in a bottom-up process.

- Consider establishing a Nordic young diplomats' network on peace and conflict, where young Nordic diplomats and development professionals working on peace and conflict can share their experiences and establish connections.

- Examine the possibility of joint training and education for entry level staff on Nordic approaches to peace and security, including negotiation tactics, based on an existing annual course run by the Folke Bernadotte Academy in Sweden for the Swedish diplomatprogrammet and the Norwegian aspirantprogrammet.

- Consider convening annual, informal meetings between representatives of the units in the ministries of foreign affairs working with peace and conflict resolution in the respective Nordic countries. While the facilitation of peace talks does not lend itself to close Nordic cooperation due to the confidential nature of the endeavor, it might be valuable to have meetings between representatives of the respective departments of peace and mediation for informal coordination and experience sharing.

- Enhance non-exclusive Nordic cooperation, building broad coalitions and global initiatives where relevant.

- Support the implementation of the Nordic colocation goals formulated in 2012 by the Nordic Council of Ministers, including the demonstration of the political priority of streamlining or in other ways overcoming administrative, legal, security, procedural and other differences.

5. Policy analysis

- Pilot joint Nordic analysis mechanisms at the country level in conflict zones.

- Look into establishing a policy-oriented Nordic Dialogue Center, which provides conflict analysis for the Nordic agencies working with peace and conflict resolution.

- Commission an analysis of synergies in Nordic peacekeeping specifically in relation to women, peace and security and prevention, with the aim of thinking about new joint initiatives in this area.

- Develop joint report on lessons learned from colocation efforts in Yangon, Kabul and other capitals in conflict-affected countries in which multiple Nordics are involved to learn about the limitations and potentials of these particular cases of working together. 
- Compile an overview of the financial and human resources from each of the Nordic countries allocated for peacebuilding, including peace mediation support to peace processes, prevention and sustaining peace, to be made in adherence with a previous recommendation from the Nordic Council. ${ }^{2}$

6. Research

- Support the establishment of a Peace Research in the Nordic countries (PRIN) academic conference, drawing inspiration from the biennial, academic conference, Peace Research in Sweden (PRIS). The conference would be a platform for Nordic Peace Research institutions to engage regularly.

- Allocate resources (via NordForsk) to a Nordic Centre of Excellence within peace and conflict resolution, which would foster cooperation among the strong Nordic centers within the field and draw on the longstanding traditions pertaining to Nordic peace research.

- Promote a Nordic competence environment within peace and climate change.

\footnotetext{
2 The precise formulation: "att Nordiska rådet i samarbete med de nationella utrikesutskotten samlar information om hur mycket som de facto totalt används i de nordiska länderna på fredsförmedling, både ur stadsbudgetar och privata finansieringskällor" (Nordic Council 2016).
} 


\section{Conclusions}

Based on interviews with practitioners working with Nordic efforts related to cooperation, peace and reconciliation on a daily basis, we conclude that:

- The Nordics use relatively different terminologies concerning peace and conflict resolution.

- The idea of a Nordic Peace brand resonates with those working with Nordic cooperation and peace and reconciliation.

- The Nordic Peace brand is a part of the general Nordic brand but has distinct features related to two dimensions: Values and ways of working.

- Both in terms of values and ways of working, the Nordic culture is very similar across the different countries.

- The Nordics work together on peace and reconciliation in three different degrees:

- The Nordics engage in coordination, which primarily involves the sharing of information and analysis.

- The Nordics engage in cooperation, which is slightly more institutionalized, where information sharing leads to joint activities and some sort of division of labour, albeit based on each country starting from their own priorities.

- The Nordics engage in collaboration, which is the most integrated form of policy work. Here, joint information gathering and analysis is the basis of joint priorities, leading to a division of labour or a rotation of labour.

- The benefits of Nordic cooperation count amplified impact, extended information, similar working cultures, trust and shared values.

- The challenges to Nordic cooperation relate to issues of secrecy and confidentiality, which are particularly crucial in mediation processes, as well as differing systems and setups that complicate cooperation and coordination.

- There is momentum and an increasing appetite for Nordic cooperation among practitioners in light of current developments in global affairs.

- Women, peace and security is an emerging area of Nordic cooperation, which could be furthered and promoted as part of a Nordic Peace brand.

- Conflict prevention and preventive diplomacy are areas, where Nordic cooperation could be strengthened to take advantage of synergies and division of labour.

- In the past decade, practical forms of working together such as colocation have tended to increase the degree of policy integration in fragile and conflict-affected states.

- Establishing networks could be an effective way to strengthen Nordic cooperation within peace and conflict resolution in a cost-effective and organic way.

- There is a growing tendency regarding non-exclusive Nordic cooperation whereby Nordics work together with other like-minded countries for a common purpose. 


\section{About the authors}

Anine Hagemann is a diplomat on leave from the Danish Ministry of Foreign Affairs, currently writing a $\mathrm{PhD}$ on peacebuilding and conflict resolution at the Center for Resolution of International Conflicts (CRIC) at the Department of Political Science, University of Copenhagen. She has worked with foreign and development policy related to fragile states, human rights and security for Denmark and the United Nations Department of Peacekeeping, including deployments to Nepal and South Sudan. She is operational partner in the Nordic Women Mediators (NWM).

Isabel Bramsen (Ph.d.) is a post-doctoral researcher at Center for Resolution of International Conflicts (CRIC) at the Department of Political Science, University of Copenhagen. She has written several books and articles on conflict resolution, mediation and nonviolent resistance in the MENA-region. She is operational partner in the Nordic Women Mediators (NWM) and former chairperson of the Danish Council on Conflict Resolution (RIKO).

Thank you to all of the representatives in the Nordic Ministries of Foreign Affairs, development agencies and the policy-makers and scholars who donated their time and energy to sharing their thoughts about Nordic peace efforts with us. Thank you to Sara Dybris Mcquaid, Christine Nissen, Anders Wivel, Ole Wæver and Øyvind Svendsen for great comments on our findings. Thank you to Rachel Scott from the OECD for her assistance with statistics and to Håvard Lundberg for assistance with tables, figures and models. Thanks also to Cecilie Overgaard Thomsen for research assistance and to Josephine Nielson Svensson and Arne Fogt Bergby at the Nordic Council and Nordic Council of Ministers for their continual support. 


\section{References}

Archer, Clive (1996). The Nordic Area as a "Zone of Peace". Journal of Peace Research, 33(4): pp. 451-467. https://doi.org/10.1177/0022343396033004006

Ball, Nicole, Sue Emmott, Maja Greenwood, Najib Murshed, \& Pablo Uribe (2016). Udviklingssamarbejde i Afghanistan. Erfaringsopsamling 2001-2014. Del II. Danish Institute for International Studies, in collaboration with Landell Mills.

Bauck, Petter, \& Arne Strand (2009). Strengthening Nordic Development Cooperation in and with Afghanistan. Norad Report Discussion 3/2009.

Bramsen, Isabel, Jørn B. Nielsen, \& Vibeke Vindeløv (2016). International Konfliktløsning. Copenhagen: Samfundslitteratur.

Brommesson, Douglas (2018a). Introduction to Special Section: From Nordic Exceptionalism to a Third Order Priority - Variations of "Nordicness" in Foreign and Security Policy. Global Affairs. https://doi.org/10.1080/23340460.2018.1533385

Brommesson, Douglas (2018b). "Nordicness" in Swedish Foreign Policy - From Mid Power Internationalism to Small State Balancing? Global Affairs.

https://doi.org/10.108o/23340460.2018.1516116

Browning, Christopher S. (2007). Branding Nordicity: Models, Identity and the Decline of Exceptionalism. Cooperation and Conflict, 42(1): pp. 27-51. https://doi.org/10.1177/0010836707073475

The Danish Ministry of Defense 2014. Stolenberg-rapporten: Status pr. maj 2014. Notat. https://www.ft.dk/samling/20131/almdel/UPN/bilag/210/1367947/index.htm [accessed 11 February 2019]

The Danish Ministry of Foreign Affairs (2015a). Nordisk og nordisk-baltisk udenrigsministermøde i Helsingør den 5.-6. maj. Press release. http://um.dk/da/udenrigspolitik/udenrigspolitiske-nyheder/newsdisplaypage/?newsid=6ege79a6-9d8c-4a13-8b8c-9df1c7429egd [accessed 11 February 2019]

Danmarks samtænkte freds- og stabiliseringsindsatser 2017 (2017). https://www.ft.dk/samling/20171/almdel/FOU/bilag/84/1883226.pdf

The Danish Ministry of Foreign Affairs (2015b). Erklæring fra det nordiske udenrigsministermøde. http://um.dk/da/nyheder-fra-udenrigsministeriet/newsdisplaypage/?newsid $=4428 c a 5 b-c 522-49 b b-b 6 d f-36428995682 b$ [accessed 11 February 2019]

Danish government 2017. The World 2030: Strategy for Danish Development Cooperation and Humanitarian Action http://amg.um.dk/en/policies-and-strategies/stategy-for-danish-development-cooperation/

Danish government 2018. Foreign and Security Policy Strategy 2019-2020 http://um.dk/en/news/NewsDisplayPage/?newsID=01FC577B-6BF2-4FD7-8572-5AFo534CF599

The Danish Ministry of Foreign Affairs (2018). Statement from the Nordic Foreign Ministers on Iran. http://um.dk/en/news/newsdisplaypage/?newsid=f8601d45-2300-4ae5-b202-95af6219a541 Deutsch Karl, W., Sidney A. Burrell, Robert A. Kann, Maurice Lee Jr., Martin Lichtermann, Raymond E. Lindgren, Francis L. Loewenheim, \& Richard W. Van Wagenen (1957). Political Community and the North Atlantic Area. Princeton, NJ: Princeton University Press.

Finnish Government 2016. Government Report on Finnish Foreign and Security Policy https://valtioneuvosto.fi/documents/10616/1986338/VNKJog2016+en.pdf/b33c3703-29f44cce-ag10-bo5e32b676bg 
Graeger, Nina (2011). Norden in a Changing Global Order. In: T. Tiilikainen \& K. Korhonen (eds), Norden - Making a Difference? Possibilities of Enhanced Nordic Cooperation in International Affairs. The Norden 2020 project report. FIIA REPORT 29. Helsinki: The Finnish Institute of International Affairs.

Græger, Nina (2018). Need to Have or Nice to Have? Nordic Cooperation, NATO and the EU in Norwegian Foreign, Security and Defense Policy. Global Affairs.

https://doi.org/10.1080/23340460.2018.1492351

Haugevik, Kristin, \& Ole Jacob Sending (2019). Norden i verden. NUPI Skole nr. 1. https://www.nupi.no/Skole/HHD-Artikler/2019/Norden-i-verden

Hiltunen, Kati (2018). Just Another Cold, Faraway Nordic Country? Finland in China. Master's Thesis at the University of Helsinki. https://helda.helsinki.fi/bitstream/handle/10138/235714/Hiltunen_Kati_Pro_gradu_2018.pdf

Herolf, Gunilla, Sia Spiliopoulou Åkermark, Maria Ackrén, \& Lise Lyck (2015). The Nordic Autonomous Regions from a Peace Perspective. Norden: http://norden.diva-portal.org/smash/get/diva2:815076/FULLTEXTo2.pdf

Hyde-Price, Adrian (2018). Epilogue: "Nordicness" - Theory and Practice. Global Affairs. https://doi.org/10.1080/23340460.2018.1497451

Icelandic Government 2017. Althingi Government Agreement https://www.stjornarradid.is/lisalib/getfile.aspx?itemid=coc3c70a-051d-11e8-9423$005056 \mathrm{bc} 4 \mathrm{~d} 74$

Internasjonal strategi for Nordisk råd 2018-2022 (2018). https://www.norden.org/da/node/7594 Jakobsen, Peter Viggo (2005). Nordic Approaches to Peace Operations: A New Model in the Making? Taylor and Francis.

Lethi, Marko (2019). The Era of Private Peacemakers: A New Dialogic Approach to Mediation (Rethinking Peace and Conflict Studies. Palgrave.

Tarja Väyrynen, Marko Lehti, Élise Féron, Sara Koopman, \& Marko Lethi (2019). Inclusive Mediation and Conflict Prevention: The Finnish Model. Publication series of the Government's analysis, assessment and research activities. http://julkaisut.valtioneuvosto.fi/bitstream/handle/10024/160599/16-2018-Inclusive\%20Mediation\%20and\%20Conflict\%2oPrevention.pdf

Lethi, Marko (ed.) (2014). Nordic Approaches to Peace Mediation. Research, Practices and Policies. TAPRI Studies in Peace and Conflict Research No. 101. Tampere: Tampere Peace Research Institute.

Morgenstierne, Christopher Munthe (2003). Denmark and National Liberation in Southern Africa. Uppsala: Nordiska Afrikainstitutet. http://www.diva-portal.org/smash/get/diva2:241390/FULLTEXTo1.pdf

Mouritzen, Hans (1995). The Nordic Model as a Foreign Policy Instrument: Its Rise and Fall. Journal of Peace Research, 32(1): pp. 9-21. https://doi.org/10.1177/0022343395032001002

Nordic Council of Ministers (2016). Medlemsförslag om att förstärka fredsförmedling som ett nordisk varumärke. https://www.norden.org/sites/default/files/session_documents/555612695A\%201698_presidiet.pdf/A_1698_presidiet.pdf [accessed 11 February 2019]

Nordic Council of Ministers (2017a). Låt Fred Blive Nordens Varumärke. https://www.norden.org/en/node/4403

Nordic Council of Ministers (2017b). Reply 26/2017 to the budget for 2018. https://www.norden.org/sites/default/files/session_documents/176889850Meddelelse\%20om\%2oRek.\%2026_2017\%20-\%20Budget\%202018.pdf/Meddelelse_om_Rek._26_2017_-_Budget_2018.pdf

Nordic Ministers for Foreign Affairs (2012). Nordic Diplomatic Cooperation. https://www.stjornarradid.is/media/utanrikisraduneyti-media/media/Frettatilkynning/Yfirlysing-um-samvinnui-sendiradarekstri.pdf

Norwegian government 2018. Foreign Minister's Foreign Policy Address to the Storting on 27 February 2018 https://www.regjeringen.no/en/aktuelt/storting_address180227/id2591293/ 
OECD (2018). Official Development Aid Dataset, https://stats.oecd.org/Index.aspx?DataSetCode=CRS1\#

Ojanen, Hanna (2005). Finland: Rediscovering its Nordic Neighbors after an EU Honeymoon? Security Dialogue, 36(3): pp. 407-411. https://doi.org/10.1177/og67010605057971

Hanna Ojanen \& Tapio Raunio (2018). The varying degrees and meanings of Nordicness in Finnish foreign policy, Global Affairs, 4:4-5, pp. 405-418. https://doi.org/10.108o/23340460.2018.1533386

Olesen, Mikkel R., \& Anders Wivel (2015). Hvad blev der af den klassiske Kold Krigs-aktivisme?: Den nordiske dimensionen i dansk udenrigspolitik. Politik, 18(4): pp. 14-24.

https://doi.org/10.7146/politik.v18i4.27624

Oxfam and the Swedish Committee for Afghanistan (2018). Aid Effectiveness in Afghanistan. https://reliefweb.int/sites/reliefweb.int/files/resources/aid_effectiveness_in_afhganistan_march_2018_o.pdf

Folke Bernadotte Academy, FBA (2016). Ökat svenskt engagemang i medling och dialogprocesser för konfliktlösning.

Riis Andersen, Louise (2016). Den international indsats i Afghanistan hang ikke sammen. DIIS rapport. https://www.diis.dk/publikationer/internationale-indsats-afghanistan-hang-ikkesammen

Runge Olesen, Mikkel (2017). Activism with the Nordic "Brothers": Cautious Revival after Years of Decline? Politica 49(4).

Runge Olesen, Mikkel (2018). To Balance or Not to Balance: How Denmark Almost Stayed out of NATO, 1948-1949. Journal of Cold War Studies, 20(2): pp. 63-98.

https://doi.org/10.1162/jcws_a_00818

Roth Michèle, \& Cornelia Ulbert (2018). Cooperation in a Post-Western World: Challenges and Future Prospects (Global Trends. Analysis 01). Bonn: Development and Peace Foundation

Schouenborg, Laust (2013). The Scandinavian International Society: Primary Institutions and Binding Forces, 1815-2010. London: Routledge, pp. 1-190.

Sellström, Tor (2003). Preface to Christopher Munthe Morgenstierne, Denmark and National Liberation in Southern Africa. Uppsala: The Nordic Africa Institute. http://www.diva-portal.org/smash/get/diva2:241390/FULLTEXTo1.pdf

Sherriff, Andrew, Pauline Veron, Matthias Deneckere, \& Volker Hauck (2018). Supporting Peacebuilding in Times of Change, SIPRI Evaluation Report, September 2018, available at: https://www.sipri.org/sites/default/files/2018-11/ecdpm-2018-supporting-peacebuildingtimes-change-synthesis-report.pdf

Swedish government 2018. Handbook: Sweden's feminist foreign policy https://www.government.se/reports/2018/08/handbook-swedens-feminist-foreign-policy/

Swedish government 2018. Policy for global development in the implementation of the 2030 agenda https://www.government.se/legal-documents/2018/03/policy-for-global-development-in-theimplementation-of-the-203o-agenda/

Thorhallsson, Baldur, \& Petúr Gunnarson (2017). Iceland's Relations with its Regional Powers. NUPI Working Paper. https://brage.bibsys.no/xmlui/bitstream/handle/11250/2441710/NUPI_Working_Paper_874_Thorhallsson_Gunnarsson.pdf?sequence $=2$

Wivel, Anders (2017). What Happened to the Nordic Model of Peace and Security? Peace Review: A Journal of Social Justice, 29: pp. 489-496.

Anders Wivel (2018) Forerunner, follower, exceptionalist or bridge builder? Mapping Nordicness in Danish foreign policy, Global Affairs, 4:4-5, pp. 419-434.

https://doi.org/10.1080/23340460.2018.1557016 


\section{Sammenfatning}

Denne rapport kortlægger hvordan de nordiske lande samarbejder inden for fred og konfliktløsning. Rapporten ser på den nordiske tradition for at støtte fred og konfliktløsning globalt, og vurderer tilstedeværelsen og værdien af at have Fred som Nordens Varemærke. Vi finder, at Fred som Nordens Varemærke generelt består af to elementer: fælles kerneværdier og arbejdsmetoder. Med hensyn til kerneværdier undersøger vi hvordan og hvorvidt mægling, dialog, menneskerettigheder, civilsamfund og kvinder, fred og sikkerhed kan være en del af Nordens varemærke. I forhold til arbejdsmetoder viser rapporten hvordan fælles nordisk arbejde inden for fred og konfliktløsning er drevet af fælles arbejdskultur, værdier, pragmatisme og praktiske løsninger. Rapporten kategoriserer tre forskellige grader af samarbejde: koordination, som den mindst integrerede tilgang, der primært involverer informationsdeling og opbygning af tillid; kooperation, som en mere ritualiseret, men alligevel politisk ikkebindende form for samarbejde; og kollaboration, som en mere regelmæssig, integreret og i nogle tilfælde mere bindende tilgang, hvor fælles analyser fører til fælles formulering og løsning af problemer. Rapporten viser, at de nordiske lande tit er forbeholdne overfor at formalisere samarbejdet, men at der generelt er appetit på at samarbejde yderligere, både på grund af de praktiske fordele heraf, men også grundet geopolitiske forskydninger og de nuværende tilbageskridt for multilateralisme og internationale normer. Mens visse områder kan være mere udfordrende for fælles indsatser, tæller fordelene ved at samarbejde potentialet for øget indflydelse, muligheden for at være hinandens forlængede arm samt at samarbejde generelt flyder nemt grundet fælles arbejdskulturer, værdier og tillid. Til sidst kommer vi med en række anbefalinger vedrørende yderligere fælles nordiske projekter og potentielle samarbejdsmekanismer inden for fred og konfliktløsning. Vi foreslår helt overordnet at nordisk samarbejde styrkes på to områder: kvinder, fred og sikkerhed samt forebyggende diplomati, og at dette gøres ikke blot i en nordisk kontekst men i samarbejde med regionale og globale aktører via det vi kalder "ikkeeksklusivt nordisk samarbejde". 
Nordic Council of Ministers

Nordens Hus

Ved Stranden 18

DK-1061 Copenhagen $\mathrm{K}$

www.norden.org

\section{New Nordic Peace - Nordic Peace and Conflict Resolution Efforts}

For a long time, the Nordic countries have been a region of peace, with the ability to resolve conflicts peacefully among themselves, and a region for peace, actively promoting peace globally. While efforts to actively brand the Nordic region are ongoing, the Nordic Peace brand is an area with untapped potential. The Nordics have rich traditions for working together within peace and conflict resolution. These joint efforts have grown organically and informally from like-mindedness, letting the common Nordic culture and ways of working foster integration among them where relevant. The people working in the Nordic countries on Nordic cooperation and peace recognize the potential of strengthening the Nordic Peace brand. Areas of special potential include increasing focus on the shared Nordic priorities of prevention and the women, peace and security agenda as well as fostering Non-exclusive Nordic cooperation with global partners as part of the Nordic Peace brand. 